AUSTRALIA-JAPAN RESEARCH CENTRE

ANU COLLEGE OF ASIA \& THE PACIFIC

CRAWFORD SCHOOL OF ECONOMICS AND GOVERNMENT

\title{
NEGATIVE IMPACTS OF CAPITAL INJECTION POLICIES ON THE CAPITAL CRUNCH: EVIDENCE FROM JAPAN
}

Takeshi Osada 


\section{ASIA PACIFIC ECONOMIC PAPER NO. 391 \\ 2011}

\section{NEGATIVE IMPACTS OF CAPITAL INJECTION POLICIES ON THE CAPITAL CRUNCH: EVIDENCE FROM JAPAN}

Takeshi Osada

AUSTRALIA-JAPAN RESEARCH CENTRE CRAWFORD SCHOOL OF ECONOMICS AND GOVERNMENT 
Asia Pacific Economic Papers

\section{ANU COLLEGE OF ASIA \& THE PACIFIC}

(C) TAKESHI OSADA, 2011.

This work is copyright. Apart from those uses which may be permitted under the Copyright Act 1968 as amended, no part may be reproduced by any process without written permission.

Asia Pacific Economic Papers are published under the direction of the Editorial Committee of the Australia-Japan Research Centre (AJRC). Members of the Editorial Committee are:

Professor Jenny Corbett

Executive Director

Australia-Japan Research Centre

The Australian National University, Canberra

Professor Christopher Findlay

Professor of Economics

University of Adelaide

Adelaide, South Australia

Dr Kazuki Onji

Crawford School of Economics and Government

The Australian National University, Canberra

Papers submitted for publication in this series are subject to double-blind external review by two referees. The views expressed in APEPs are those of the individual authors and do not represent the views of the Australia-Japan Research Centre, the Crawford School, or the institutions to which authors are attached.

The Australia-Japan Research Centre is part of the Crawford School of Economics and Government, The Australian National University, Canberra.

ISSN 07288409

ISBN 978-0-86413-343-4

AUSTRALIA-JAPAN RESEARCH CENTRE

CRAWFORD SCHOOL OF ECONOMICS AND GOVERNMENT

THE AUSTRALIAN NATIONAL UNIVERSITY

CANBERRA ACT 0200

TELEPHONE: $(612) 61253780$

FACSIMILE: $(612) 61258448$

E-MAIL: AJRC@ANU.EDU.AU

URL: HTTP://WWW.CRAWFORD.ANU.EDU.AU 


\title{
NEGATIVE IMPACTS OF CAPITAL INJECTION POLICIES ON THE CAPITAL CRUNCH: EVIDENCE FROM JAPAN
}

\author{
Takeshi Osada ${ }^{*}$
}

\begin{abstract}
This paper empirically investigates the effects of capital injections into Japanese banks, which were based on the Financial Function Stabilization Law and the Early Strengthening Law, on the capital crunch. Using financial panel data for all of the Japanese commercial banks, we estimate dynamic panel models which investigate the effects of capital injections on banks' lending behaviour. We find a negative impact of capital injections on their lending behaviour. This finding is different from that of previous studies, which concluded that capital injections had positive effects. Though the capital injections were expected to free banks from capital regulatory constraint, Japanese banks that had received capital injections became more sensitive about their capital adequacy ratios, and reduced their loans; the exception was the domestic banks that received capital injection based on the Early Strengthening Law. The difference between success and failure has a lot to do with the frameworks of capital injection policies, suggesting that the manner of conducting capital injection policies and banking supervision is a very crucial matter.
\end{abstract}

JEL codes: G21; G28; C23; E51

Keywords: Capital Injection, Capital Crunch, Basel Accord

Assistant Professor, Faculty of Service Management, Bunri University of Hospitality, Saitama, Japan t.osada@mercury.ne.jp

${ }^{\dagger}$ Visiting Program Associate in the College of Asia and the Pacific, Crawford School of Economics and Government at the Australian National University, Canberra, Australia 


\section{Introduction}

The Japanese banking sector received huge capital injections of taxpayers' money during two financial crises: the first, from the 1990s to the mid-2000s, caused by the collapse of the Japanese asset price bubble, and the second, the current global financial crisis from 2008 onwards. The total amount of taxpayers' money that has been injected into the Japanese banking system is over $¥ 12$ trillion, or 2\% of Japan's nominal GDP in 2008. Not only in Japan, but also in many other countries, have governments spent much of taxpayers' money on capital injections into the troubled banking sector. ${ }^{\ddagger}$ At this moment, the capital injection policy is one of the universal used economic recovery policies.

Although the goals of the capital injection policies are manifold and slightly differ between countries and eras, avoiding a 'capital crunch' is one of the common goals of every capital injection plan. So what is the 'capital crunch'? According to the definition of Peek and Rosengren (1995), a capital crunch is "the bank shrinkage resulting from binding capital requirements." Under the Basel Capital Accord (Basel I), banks shrink their risk assets—especially their bank loans—if their capital decreases. Peek and Rosengren (1995) reported that this capital crunch was observed over the period of 1990 and 1991 in the United States.

A capital crunch usually happens during a period of recession or depression, when banks' capital base is likely being eroded by loan losses and so on. However,

\footnotetext{
${ }^{\ddagger}$ In coping with the current global financial crisis, about $\$ 700 \mathrm{BN}$ and $\bullet 310 \mathrm{BN}$ have been provided as capital injection funds in the U.S. and the EU (i.e., the 27 European member countries), respectively.
} 
even if their capital deteriorates, a capital crunch does not occur if banks are able to raise additional capital through financial markets. However, it is difficult or costly for banks to raise fresh external capital in bad times. Therefore banks will be forced to cut back on their lending activities. This is the reason why governments have made capital injections into banking sectors during financial crises. The increased banks' capital base by this policy is expected to prevent banks from reducing their loans, or in other words, to avoid a capital crunch.

Montgomery and Shimizutani (2009) is one of the key studies on the effects of bank recapitalization policies on the capital crunch. They examine bank recapitalization policies in Japan from FY 1997 through FY 1999, and reveal that capital injections have increased domestic lending, in particular to small and medium enterprises (SMEs). Watanabe (2007) also shows that an increase in capital mainly due to a capital injection in FY 1998 had likely induced capital-constrained banks to accelerate supply of loans.

However, some data suggests the possibility that Japanese companies had been suffering a credit crunch - the reduction in credit supply available to borrowers for several years in the 2000 s, which is the period excluded from the analysis of previous studies. Figure 1 illustrates the total amount of loans of the Japanese banking sector from March 1990 to March 2007. We can see that this amount gradually decreased from the end of the 1990s — when the capital injection policy was first introduced - to the mid-2000s.

Also, we can see that Japanese firms, especially small companies, had faced difficulties in obtaining loans from banks from the late 1990s to the early 2000s. 
Figure 2 shows the Bank of Japan's (BOJ's) Tankan "Lending Attitude of Financial Institutions” Diffusion Indices (DIs) from 1990:1Q through 2007:4Q ${ }^{\S}$ These DIs represent the "accommodative" minus the "severe" percentage points about the present lending attitude of financial institutions (Motonishi and Yoshikawa [1999]).

These data show that the capital injections may not have prevented the capital crunch, in other words, could not have accelerated supply of loans for several years in the 2000s, which is the period excluded from the analysis of previous studies. Therefore, using data from the period including the early 2000 s, this research reexamines whether capital injections had a positive impact on the banks' lending behaviour as previous studies showed.

The main contributions of this paper are twofold. First, we demonstrate a negative impact of capital injections on the capital crunch ${ }^{*}$. Though the capital injections were expected to free banks from binding capital requirements, the international banks that had received capital injections became more sensitive than before about their capital adequacy ratios, and reduced their loans. This result is different from those of previous studies, which showed positive effect of capital injections on the capital crunch. Second, we find asymmetric effects on

\footnotetext{
$\$$ "The BOJ Tankan (Short-term Economic Survey of Corporations) is based on the quarterly survey conducted by the Bank of Japan about the present and future business conditions facing the Japanese firms. The survey started in 1957 and is considered to be one of the most important information for the Bank of Japan to conduct monetary policy (Motonishi and Yoshikawa [1999])".

"* In this paper, a 'negative effect' of capital injections on the capital crunch means the situation that capital injections confound the capital crunch. On the other hand, a 'positive effect' is that capital injections ease it.
} 
international and domestic banks. Unlike the international banks, domestic banks that received capital injections became less sensitive about their capital adequacy ratios and increased their loans. This means that the capital injections did ease the capital crunch of domestic banks. These two results show the evidence that capital injections do not necessarily prevent a capital crunch, which suggests that the manner of conducting capital injections is an important matter.

The rest of this paper is organized as follows. Section 2 summarizes the relationship between the capital crunch and capital injection policies. Section 3 describes the empirical specifications and the data, as well as the results of our regression analysis. Section 4 concludes this paper.

\section{Capital Crunch and Capital Injection Policies}

\subsection{The Basel Accord and Capital Crunch}

The phenomenon 'capital crunch' is the credit crunch caused by the drop in bank capital. It is thought that this phenomenon is caused by the Basel regulatory framework (Basel I). Peek and Rosengren (1995), one of the studies on the credit crunch at the beginning of 1990s in New England in the U.S., discovered this phenomenon at that time, and defined the capital crunch as "the bank shrinkage resulting from binding capital requirements."††

This regulatory framework, the so-called Basel Accord, was adopted in July 1988. From the end of that year, international banks from the G10 countries have

\footnotetext{
${ }^{\dagger \dagger}$ Bernanke and Lown (1991) is well known as the seminal research on the credit crunch over the period of 1990 and 1991 in the U.S.
} 
to satisfy the minimum risk-based capital (RBC) ratio, known as the BIS ratio in Japan. ${ }^{\ddagger \ddagger}$ This ratio is calculated as follows;

$$
R B C \text { ratio }=\frac{\text { Tier I capital }+ \text { Tier II capital }}{\text { Risk Weighted Assets }}
$$

Tier I capital is shareholders' equity, which consists of banks' capital stock and internal reserves, and Tier II capital could include hybrid debt capital instruments such as subordinate debts (with an original maturity of at least 5 years), $45 \%$ of latent revaluation reserves related to securities holding and so on. Risk Weighted Assets are defined as the sum of the risk-adjusted assets on- and off-balance sheets. On-balance sheet assets were assigned to one of five risk buckets $(0 \%, 10 \%, 20 \%$, $50 \%$ and $100 \%)$ and then weighted by the bucket's weight. For example, commercial loans are assigned to $100 \%$ risk bucket, while governments bonds issued by OECD governments to $0 \%$. Off-balance sheet contingent contracts, such as loan commitments, which are traded over the counter, need to be first converted to a credit equivalent and then multiplied by the appropriate risk weight. ${ }^{\$ \$}$

The minimum RBC ratio changed at the end of 1990 and 1992 (or for the Japanese banks, the end of March 1991 and 1993, which are the end of FY 1990 and 1992). Before the end of 1990, banks were required to keep a higher RBC ratio than each level at the end of 1987. From the end of 1990, the minimum RBC

\footnotetext{
执 The BIS ratio is named on the place where the Basel I was adopted: Bank for International Settlements (BIS).

$\S \S$ At the end of 1997 (or the end of March 1998 only in Japan), this ratio was amended to require banks to set aside capital to cover market risks, which are the risks of losses arising from movements in market price. This amendment also defined a Tier III capital to cover market risks, and allowed banks to count subordinated debt (with an original maturity of from 2-5 years) in this Tier III.
} 
ratio had been $7.25 \%$, and since the end of 1992 , it has been $8 \%$.

In the case of domestic banks, they originally did not have to satisfy this minimum RBC ratio. ${ }^{* *}$ However in Japan, from FY 1998 (April 1998-March 1999), they have had to satisfy the minimum RBC ratio of $4 \%$. The formula for calculation is slightly different from that of international banks. It does not take the $45 \%$ of latent revaluation reserves into Tier II and market risks into account. ${ }^{\mathrm{tt}}$

Under this $\mathrm{RBC}$ capital requirement, the easiest way to raise the $\mathrm{RBC}$ ratio is to shift the asset portfolio away from lending assigned with the highest risk weight of all asset buckets (100\% risk weight) to assets with less weight, which are categorized into the other buckets $(0,10,20$ and $50 \%$ risk weight). Hence banks failing to satisfy the minimum ratio have a strong incentive to cut back on lending and raise their RBC ratio, which forms the mechanism of a capital crunch. It is true that banks can raise their ratio by raising additional capital through financial markets, but it is difficult or costly for banks to raise fresh external capital, especially during a recession or depression when banks' capital base is likely being eroded by loan losses and so on. ${ }^{\ddagger \neq \ddagger}$

This phenomenon 'capital crunch' has been demonstrated by multiple studies: some examine the capital crunch at the beginning of the 1990s in the United

\footnotetext{
In this paper, 'domestic bank' means the bank which operates only within Japan, and 'international bank' mean the bank which operates not only in Japan but also overseas.

${ }^{t+t}$ The description of the RBC ratio in this section is based on that of Santos (2001), Ito and Sasaki (2002) and Himino (2005).

${ }_{\ddagger \neq \ddagger}$ One example of the costs incurred by issuing the new equity is associated with asymmetric information between investors and banks. (Watanabe[2007])
} 
States (Hall [1993], Peek and Rosengren [1995]), and others have examined it at the end of the 1990s in Japan (Ito and Sasaki [1998, 2002], Woo [2003], Watanabe [2007], Montgomery [2005]). Kashyap and Stein (2004) indicate that a capital crunch may arise even under the new Basel II regulatory framework.

\subsection{Capital Injection Policies and the Financial Revitalization Plan ${ }^{\$ S \&}$}

A capital crunch basically happens during a recession or depression, when banks' capital is likely to have been eroded and banks cannot easily raise additional capital through the financial market. Hence, in coping with such financial crises, governments have turned to capital injections in order to increase banks' capital and avoid a capital crunch. In this section, we summarize Japanese capital injection policies and the possible effects they have had on the capital crunch.

Japanese capital injection policies were conducted on the basis of two different laws (See Tables 1 and 2). The first law was the 'Financial Function Stabilization Law’, which allocated about ¥1.8 trillion to 21 banks at the end of FY 1997 (March 1998). Of the total 21, 19 were all top banks-city banks, trust banks, long-term credit banks, and Yokohama Bank. The other two were small banks, Ashikaga Bank and Hokuriku Bank. ${ }^{* \star \star *}$ Because this capital injection into the top banks was almost mandatory, the amount of injected capital was almost the same for each bank, and did not reflect the conditions of the individual banks. Even

${ }^{\$ s S}$ Section 3 of Montgomery and Shimizutani (2009) provides a detailed description of capital injections. Please refer to it for further detail.

${ }^{* * * *}$ Though Yokohama Bank is one of the regional banks, it was usually categorized as a top bank because of its large asset size in 1990s. 
Tokyo-Mitsubishi bank, which did not want to apply for a capital injection, was pressured to accept one.

The second law was the ‘Early Strengthening Law’, which spent about ¥8.6 trillion on 32 banks in the period from FY1998 to FY2001. There are some differences between this capital injection and that of the Financial Function Stabilization Law. First, the amount of money was almost five times as much as the first capital injection. A lot of money was injected to troubled banks. Secondly, this capital injection was not mandatory, so the amounts of injected capital were varied and reflected the conditions of individual banks. Under this law, Tokyo-Mitsubishi bank did not receive any capital injection. Thirdly, while most of the money under the Financial Function Stabilization Law was injected as subordinated bonds or loans, more than $80 \%$ of the money used under the Early Strengthen Law was injected as preferred stocks. As I mentioned in the previous section, subordinated bonds or loans are counted as Tier II capital, but preferred stocks are as Tier I.

Another aspect of the 'Early Strengthening Law' is the 'Financial Revitalization Plan'. The banks that received a capital injection under this second law had to submit a 'Financial Revitalization Plan', in which they had to set various numerical targets. Among them, there were the target amount of loans and the target capital ratio. ${ }^{\dagger \dagger t}$ Pursuing both these targets seems to be mutually inconsistent. Increasing loans means lowering the capital ratio, especially under the difficult conditions of raising capital by themselves. In order to keep the capital ratio high, these banks

\footnotetext{
${ }^{\dagger t t \dagger}$ These numerical targets were: a target amount of loans, target capital ratios, target profits, target labour costs, target amounts of bad loans, and so on.
} 
should decrease their loans. If these capital-injected banks received enough money to achieve the capital ratio target easily, or if the monitoring by the Financial Services Agency (FSA) of their capital ratio was not too strict, they could have increased loans independently of their capital ratio. ${ }^{\ddagger \ddagger \neq \$ S S S}$ However, if they could not, their lending behaviour would depend on their capital ratio, which would form the capital crunch.

Not only in this case, but also in the case of every capital injection, if injection money is not enough to free banks from capital regulatory constraint, the capital crunch may not be resolved. Moreover, if the capital-injected banks have to be sensitive to their capital ratio because of increased regulatory scrutiny, the capital crunch may be aggravated.

Comparing the frameworks of these two laws, the 'Early Strengthening Law', rather than the 'Financial Function Stabilization Law', is on a larger scale, and the injected capitals were tailored to individual banks. From this viewpoint, the 'Early Strengthening Law' may have acted to ease the capital crunch. On the other hand, this law seems to have been stricter, which means that it may have aggravated the capital crunch.

In summary, capital injection policies can have positive and negative effects on the capital crunch. We will now look at which effects were observed in the Japanese

\footnotetext{
执拉 And vice versa: if the monitoring by FSA on their lending behavior was not too strict, they could have achieved the target capital ratio independently of their lending behavior.

${ }^{\text {ssss }}$ Hereafter, the banks which have had capital injected are referred to as 'capitalinjected banks'.
} 
banking sector from the 1990s to the mid-2000s.

\section{Empirical Analysis}

\subsection{Method}

Our aim is to analyse the effectiveness of the capital injections on bank lending behaviour, which is analogous to that of Montgomery and Shimizutani (2009). Since we are examining the same policy as they did, we adopt the same approach with some modification. In our empirical analysis, we use the rational expectations model of bank behaviour presented in Montgomery (2005) and Montgomery and Shimizutani (2009):

$$
\begin{aligned}
\Delta \log \left(L_{i, t+1}\right)= & \alpha_{0}+\alpha_{1} \Delta \log \left(L_{i, t}\right)+\beta_{1} \operatorname{Cap}_{i, t}+\gamma_{1}\left(r_{t}^{L}-r_{t}^{D}\right) \\
& +\gamma_{2} \Delta \log \left(G D P_{t+1}\right)+\varepsilon_{i, t+1}
\end{aligned}
$$

where $\Delta \log \left(L_{i, t}\right)$ is the annual growth rate of loans of bank $i$ in FY $t$. The growth rate in year $t+l$ is regressed upon lagged growth, the bank's individual capital ratio, $\mathrm{Cap}_{i, t}$, and the differential between the interest rates on loans and on deposits, $r_{t}^{L}-r_{t}^{D}$, and the annual growth rate of nominal GDP in FY $\mathrm{t}+\mathrm{l}$. The differential between loan and deposit interest rates and the GDP growth are included to account for macroeconomic or loan demand conditions, so these two variables are assumed to be exogenous. According to Montgomery (2005) and Montgomery and Shimizutani (2009), we then assume that $\varepsilon_{\mathrm{i}, \mathrm{t}+1}$ is a rational expectation error term, which is serially uncorrelated and orthogonal to information available at time 
$t$. The expectation conditional on information available at time $t, I_{\mathrm{t}}$, is $\mathrm{E}\left[\varepsilon_{i, t+1} \mid I_{t}\right]=$ 0 , suggesting that period $t$ instruments are valid.

We assume that there are some benefits to maintaining a high capital ratio. These benefits may be twofold: decreased regulatory scrutiny and the benefit of being able to make decisions on loan supply more independently of capital constraints. Therefore $\beta_{1}$ is expected to be positive; however, if the banks' capital ratios are high enough to be free from capital regulation, this coefficient shall not be significant.

We would like to know whether the capital-injected banks were freed from capital regulation by capital injection policies, or whether the capital-injected banks were bound by capital regulations more strictly because of regulatory authority scrutiny. In order to examine this, we will modify this equation as follows:

$$
\begin{aligned}
\Delta \log \left(L_{i, t+1}\right)=\alpha_{0}+\alpha_{1} \Delta \log \left(L_{i, t}\right)+ & \beta_{1} \operatorname{Cap}_{i, t}+\gamma_{1}\left(r_{t}^{L}-r_{t}^{D}\right)+\gamma_{2} \Delta \log \left(G D P_{t+1}\right) \\
& +\beta_{2} \operatorname{Cap}_{i, t} \cdot \operatorname{Inj} D_{i, t+1}+\delta_{1} \operatorname{Inj}_{i, t+1}+\varepsilon_{i, t+1}
\end{aligned}
$$

where $\operatorname{Inj} D_{i, t+1}$ is a dummy variable: $\operatorname{Inj} D_{i, t+1}=1$ if bank $i$ had any injected funds in its liability side in year $t+l$, at the time the bank made a decision on the annual growth rate of its loans. If bank $i$ did not have any injected capital in year $t+1$, $\operatorname{Inj} D_{i, t+1}=0$.

Now, the estimation results of two coefficients, $\beta_{2}$ and $\delta_{1}$, allow us to find the effect of capital injection policies. If these banks had enough money to be free of 
capital crunch, then $\beta_{2}$ is not expected to be significantly positive, though at the same time, if their lending behaviour was activated, $\delta_{1}$ is expected to be significantly positive. This is because these banks could have freed themselves of capital regulatory constraint and increased their loans. By contrast, if the capitalinjected banks had been bound by the constraint, then the capital ratio would have affected their lending behaviour more severely. In this case, $\beta_{2}$ is expected to be positive. And if they reduced their loan, $\delta_{1}$ is to be significantly negative. These banks were more sensitive to their own capital ratios and it would be more difficult to increase their loans because they were under higher regulatory scrutiny than the other banks.

As for other coefficients, if the banks which did not have any injected capital had been bound by capital regulation, $\beta_{1}$ is expected to be positive. If not, $\beta_{1}$ is not expected to be positive.

This model introduces mechanical bias due to the dynamic structure of the model, especially in the case of a data set with an insufficiently small time dimension. As we will note in the following section, the time dimensions of our estimations are 7-14 years, which may not be long enough to ignore the bias. Following Baltagi (2001), we estimate a model with the Arellano and Bover (1995) procedure that corrects for this bias."

\subsubsection{The Financial Function Stabilization Law and Early}

Arellano and Bover (1995) developed the GMM framework for looking at efficient IV estimators for dynamic panel data models. 


\section{Strengthening Law}

As discussed earlier, the Financial Function Stabilization Law and the Early Strengthening Law, are different from each other in some respects. Under the former law, its effectiveness may have been more limited because of its smallness in scale and its uniform treatment of banks. Under the latter law, the supervision may have been stricter because of the existence of the Financial Revitalization Plan.

In order to examine the difference between these two laws, in addition to equation (1), we will estimate the following equations:

$$
\begin{aligned}
& \Delta \log \left(L_{i, t+1}\right)=\alpha_{0}+\alpha_{1} \Delta \log \left(L_{i, t}\right)+\beta_{1} \operatorname{Cap}_{i, t}+\gamma_{1}\left(r_{t}^{L}-r_{t}^{D}\right)+\gamma_{2} \Delta \log \left(G D P_{t+1}\right) \\
& +\beta_{3} \operatorname{Cap}_{i, t} \cdot \operatorname{StabD}_{i, t+1}+\delta_{2} \operatorname{StabD}_{i, t+1}+\beta_{4} \operatorname{Cap}_{i, t} \cdot \operatorname{Early}_{i, t+1}+\delta_{3} \operatorname{Early}_{i, t+1} \\
& +\varepsilon_{i, t+1}(2)
\end{aligned}
$$

where $\operatorname{StabD}_{i, t+1}=1$ if bank $i$ had funds from the Financial Function Stabilization Law in year $t+1$, and if not, $S t a b D_{i, t+1}=0$. So, $\operatorname{Early}_{i, t+1}=1$ means that bank $i$ had funds from the Early Strengthening Law in year $t+1$. In the same way as in equation (1), the estimation results of coefficients, $\beta_{3}, \delta_{2}, \beta_{4}$ and $\delta_{3}$ tell us the effects of the two capital injection laws.

\subsubsection{Scale change of the balance sheet}

Growth rate of loans might be affected by changes in the scale of the balance sheet induced by shifts in deposits. In order to control this effect of scale, we will estimate the following equations: 
No. 391, 2011

$$
\begin{array}{r}
\Delta \log \left(L_{i, t+1}\right)=\alpha_{0}+\alpha_{1} \Delta \log \left(L_{i, t}\right)+\beta_{1} \operatorname{Cap}_{i, t}+\gamma_{1}\left(r_{t}^{L}-r_{t}^{D}\right)+\gamma_{2} \Delta \log \left(G D P_{t+1}\right) \\
+\gamma_{3} \Delta \log \left(\text { Deposit }_{i, t+1}\right)+\beta_{2} \operatorname{Cap}_{i, t} \cdot \operatorname{Inj}_{i, t+1}+\delta_{1} \operatorname{Inj}_{i, t+1}+\varepsilon_{i, t+1}
\end{array}
$$

$$
\begin{array}{r}
\Delta \log \left(L_{i, t+1}\right)=\alpha_{0}+\alpha_{1} \Delta \log \left(L_{i, t}\right)+\beta_{1} \operatorname{Cap}_{i, t}+\gamma_{1}\left(r_{t}^{L}-r_{t}^{D}\right)+\gamma_{2} \Delta \log \left(G D P_{t+1}\right) \\
+\gamma_{3} \Delta \log \left(\operatorname{Deposit}_{i, t+1}\right)+\beta_{3} \operatorname{Cap}_{i, t} \cdot \operatorname{StabD}_{i, t+1}+\delta_{2} \operatorname{StabD}_{i, t+1} \\
+\beta_{4} \operatorname{Cap}_{i, t} \cdot \operatorname{Early}_{i, t+1}+\delta_{3} \operatorname{Early}_{i, t+1}+\varepsilon_{i, t+1}
\end{array}
$$

$\Delta \log \left(\right.$ Deposit $\left._{i, t+1}\right)$ is the annual growth rate of total deposits of bank $i$ in FY $t+1$, which is used to control the scale change of the balance sheet, and $\gamma_{3}$ is expected to be positive. 


\subsection{Data}

The accounting information used is the financial panel data for all of the Japanese commercial banks, city banks, long-term credit banks, regional banks, $2^{\text {nd }}$ regional banks, and trust banks. This information is from the Nikkei Financial Quest database. We use the fiscal-year-end data on an unconsolidated basis from FY1993 to FY2006. ${ }^{\mathrm{tt \dagger \dagger}}$ Mergers are accounted for by treating the merged entity as a new bank after the event.

For the interest rates on loans and deposits, we use the 'interest rates on new loans and discounts' and 'average interest rates on time deposits' respectively. For every March; these rates are from the BOJ Time-Series Data Search. ${ }^{\ddagger \neq \neq \ddagger \ddagger}$

International and domestic banks are analysed separately to preserve the homogeneity of the sample. In our sample split, international banks are defined as banks that have maintained the 8\% BIS requirement from FY1993 to FY2006, and domestic banks are banks that do not have overseas branches and subsidiaries as of year $t \cdot{ }^{\$ s s s}$ International banks whose capital ratios are less than $8 \%$ and domestic banks whose capital ratios are less than $4 \%$ have been excluded from our sample. In the case of the estimations for domestic banks, the sample period is from FY1999

\footnotetext{
${ }^{\dagger t t t \dagger}$ In June 1992, a new clause on bank capital regulation was added to the Banking Act, and it went into effect from April 1993. So, we use data from FY1993 to the latest available year: FY2006.

执擂 The data codes of interest rate on loans and deposits are 'DL'DLLR2CIDBNLl' and 'DL'DLDRK_DLDR442DB', respectively.

${ }^{\text {sssss }}$ Banks which at first opted to pursue the $8 \%$ BIS requirement but then later reverted to the domestic $4 \%$ Ministry of Finance (MOF) requirement are excluded from international banks. (Montgomery [2005], Montgomery and Shimizutani [2009])
} 
to FY2006 because we cannot obtain data on capital regulatory ratios before FY1998 from our database. In our analysis, two measures of capital ratio are used: the total capital to risk-weighted assets ratio and the core tier I ratio."

We use two variables as the dependent variable: the annual growth rate of 'Loans \& Bills Discounted' and 'Loans and Discounts for Small Business'. In accordance with the Financial Revitalization Plan, the FSA monitored the movements of the domestic and SME loans of capital-injected banks. Therefore, we use Loans \& Bills Discounted (hereafter Total Loans) and Loans and Discounts for Small Business (SME Loans) as proxies for domestic and SME loans, respectively.

Table 3 provides the summary statistics for the data used in the estimations. Although there is a difference in the sample period between the two groups, compared to the domestic banks, the international banks have a higher total capital ratio, as expected.

\subsection{Analysis}

Estimation results for international banks and domestic banks are presented in Tables 4 and 5 respectively.

First, we examine the case of international banks in Table 4. Estimation results in Panel A and B show the results of using Total Loans and SME Loans as $L_{i, t}$ respectively. In the first four columns, we use the total capital ratio as Cap ${ }_{i, t}$, and in

Studies have shown that the tier I ratio as well as the total capital ratio affected bank lending behavior. 
the last four columns, we use the Tier I ratio. Also, the last four columns show the results of using SME loans as $L_{i, t}$. Equation No., such as (1) and (2), show which equation we estimate in each column.

Looking at the middle three rows in each Panel, at the 'Total effects of the two capital injection policies (hereafter (a))', the cross-term coefficients are positive and the intercept coefficients are significantly negative. These results indicate that the capital-injected banks were not free from capital regulatory constraints but were bound by them. International banks which had received injected capital were suffering from capital crunch and decreased loans - both Total Loans and SME Loans. For example, their annual growth rates of Total Loans are about $40 \%$ lower than the rates of other international banks (see the first column in Panel A).

Focusing on each effect of the Financial Function Stabilization Law (hereafter (b)) and the Early Strengthening Law (hereafter (c)), we can find only the effects of the latter on Total Loans. The annual growth rates of Total Loans of banks which had injected money based on (c) are about $130 \%$ lower than those of other international banks (see the second column in Panel A).

Second, turning our focus to the results of domestic banks in Table 5, we are able to note differences and similarities between international and domestic banks. Looking at the middle three rows (a), almost all of the cross-term coefficients are positive and the intercept coefficients significantly negative. These results are very similar to those of international banks.

The estimation results for the effects of (b) and (c) are interesting, which are 
different from those of international banks. Though almost every coefficient in the bottom six rows is significant at $1 \%$, the results (b) and (c) are the exact opposite: in the case of (b), the cross-term coefficients are positive and the intercept coefficients are significantly negative. By contrast, in the case of (c), the cross-term coefficients are negative and the intercept coefficients are significantly positive. These results imply that although the Financial Function Stabilization Law could not have prevented a capital crunch, the Early Strengthening Law could. Capital injections based on the Early Strengthening Law helped to free domestic capitalinjected banks from capital regulatory constraint, and to increase bank loans - both Total Loans and SME Loans. For example, the annual growth rates of SME Loans for domestic capital-injected banks are about 5\% higher than those of other domestic banks. By contrast, it appears that capital injections based on the Financial Function Stabilization Law were not effective enough to help the debilitated banks, and as a result, these banks suffered from regulatory constraint.

Our empirical analysis confirms that capital injections conducted under these two laws could not prevent a capital crunch, or accelerate banks' lending. The only effective capital injections that could help free banks from capital crunch were the injections to domestic banks that were based on the Early Strengthening Law. However, this law could not help international capital-injected banks, and in fact plagued them with capital crunch. Nor could the total effects of capital injection policies help capital-injected banks. The effectiveness of these Japanese capital injections is therefore dubious. Capital injections do not necessarily prevent a capital crunch. 
Hence, the difference between success and failure may be attributed to how capital injections are conducted, as can be explained by the following two points. The first is the difference in the FSA's supervisory stance between international and domestic banks. The FSA was said to have been hard on international banks and lenient to domestic banks at that time. It is believed that international capitalinjected banks were strictly monitored by the FSA, which bound their lending behaviour to their capital ratio.

The second is the difference in the features of the Financial Function Stabilization Law and the Early Strengthening Law. As we noted in Section 2, the Early Strengthening Law was on a larger scale and its injected capitals were tailored to individual banks, unlike the Financial Function Stabilization Law. This difference can explain the different effects of the two laws on domestic capitalinjected banks. On the other hand, the Early Strengthening Law was stricter than the Financial Function Stabilization Law, which can explain the difference in effects between the two laws on international capital-injected banks.

\section{Conclusion}

This paper empirically investigated the effects of capital injection policies conducted by the Japanese government between the late 1990s and the mid-2000s. We demonstrated the possibility that capital injection policies have both positive and negative effects on capital crunch, and then examined which effects have been observed in the Japanese banking sector. Using financial panel data for all Japanese commercial banks, we estimated the dynamic panel models. 
The main contributions of this paper are twofold. First, we found that capital injections had a negative impact on capital crunch. Though the capital injections were expected to free banks from capital regulatory constraint, some Japanese banks that had received capital injections became more sensitive about their capital adequacy ratios, and reduced their loans. The exception was the domestic banks that got capital injection based on the Early Strengthening Law.

Second, we found asymmetrical effects of the Early Strengthening Law on international and domestic banks. Unlike the international capital-injected banks, domestic banks which received injections based on this law became less sensitive about their own capital adequacy ratios and increased both their Total and SME Loans. This means that the capital injections had positive effects on domestic banks' lending behaviour.

These two findings tell us that capital injections do not necessarily prevent capital crunch. We found that the difference between success and failure has a lot to do with the difference in the frameworks of capital injection policies. This finding suggests that the manner of conducting capital injection policies is a very crucial matter and the careful design of capital injection policies is very important.

We demonstrated that capital injection policies could not ease, but, in fact, plagued banks with capital crunch, which may have been the cause of a prolonged depression in Japan. What was and will be needed is a greater appreciation of the potential adverse effects that capital injection policies can have on the economy. 
Asia Pacific Economic Papers

Fig. I Total Amount of Loans of the Japanese Banking Sector (at the end of March $)^{t+t t t t}$

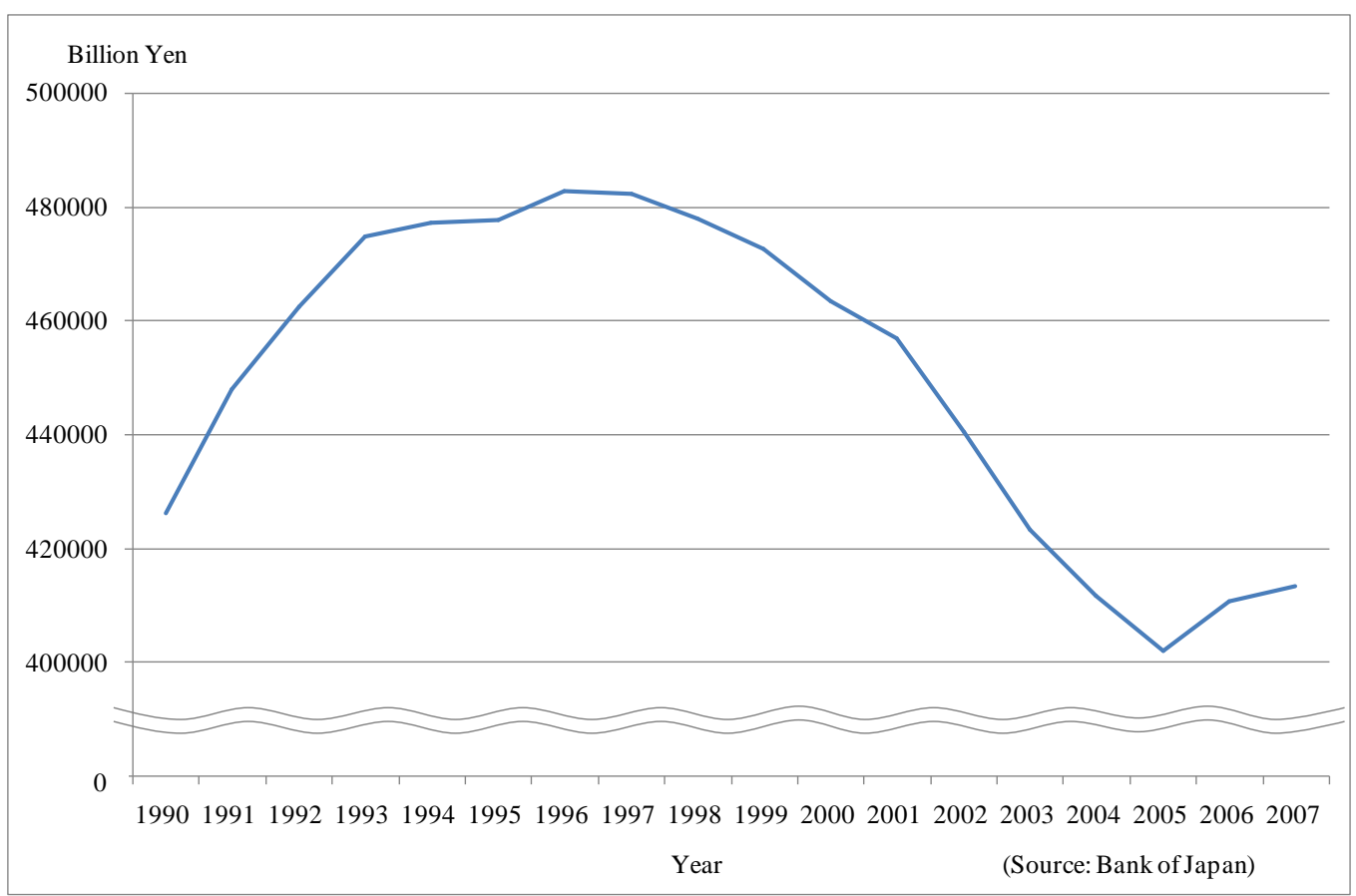

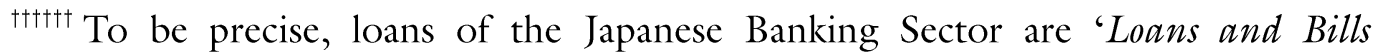
Discounted of domestically licensed banks. 
No. 391, 2011

Fig. 2 The Tankan "Lending Attitude of Financial Institutions" Diffusion Indices (DIs)

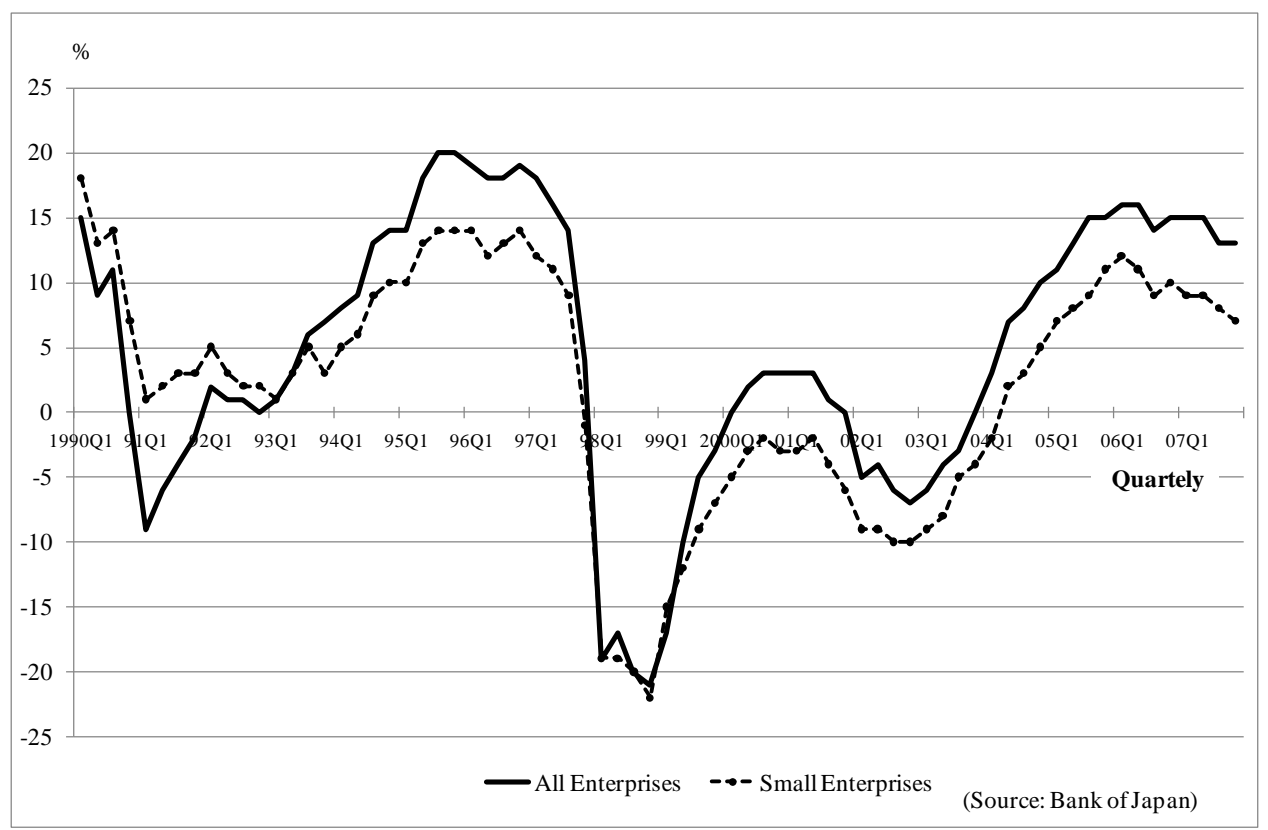

-DIs represent the "accommodative" minus the "severe" percentage points about the present lending attitude of financial institutions (quoted from Motonishi and Yoshikawa [1999]) 
Table 1 Financial Function Stabilization Law and Early Strengthening Law

\begin{tabular}{|c|c|c|c|c|c|c|}
\hline \multirow{2}{*}{ Law Name } & \multirow{2}{*}{ Total Amount } & \multicolumn{2}{|r|}{ *billion yen } & \multirow{2}{*}{$\begin{array}{l}\text { Injection } \\
\text { Periods }\end{array}$} & \multirow{2}{*}{$\begin{array}{l}\text { Number } \\
\text { of Banks }\end{array}$} & \multirow{2}{*}{$\begin{array}{c}\text { Marks } \\
\text { on Table 2 }\end{array}$} \\
\hline & & Preferred Stock & Subordinated Bonds / Loans & & & \\
\hline $\begin{array}{l}\text { Finacial Function } \\
\text { Stabilizatioin Law }\end{array}$ & 1815.6 & $\begin{array}{r}321 \\
(17.68 \%) \\
\end{array}$ & $\begin{array}{r}1494.6 \\
(82.32 \%) \\
\end{array}$ & Mar. 1998 & 21 & $\bigcirc$ \\
\hline $\begin{array}{r}\text { Early Strengthening } \\
\text { Law }\end{array}$ & 8605.3 & $\begin{array}{r}7281.3 \\
(84.61 \%)\end{array}$ & $\begin{array}{r}1324 \\
(15.39 \%)\end{array}$ & \begin{tabular}{|c|} 
Mar. 1999 \\
- Mar. 2002
\end{tabular} & 32 & \\
\hline
\end{tabular}

Table 2 Banks which received capital injections

○: Financial Function Stabilization Law, $\bullet$ : Early Strengthening Law

\begin{tabular}{|c|c|c|c|c|c|c|}
\hline Bank name & FY1997 & FY1998 & FY1999 & FY2000 & FY2001 & Current name (in 2009) \\
\hline Daiichi Kangyo & $\circ$ & $\bullet$ & & & & \\
\hline Fuji & $\circ$ & $\bullet$ & & & & Mizula \\
\hline Industrial Bank of Japan & $\circ$ & $\bullet$ & & & & IVIIZuno \\
\hline Yasuda Trust & $\circ$ & & & & & \\
\hline Sakura & $\circ$ & $\bullet$ & & & & Sumitomo Mitsui \\
\hline Sumitomo & ० & $\bullet$ & & & & 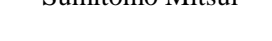 \\
\hline Tokyo Mitsubishi & ○ & & & & & \\
\hline Mitsubishi Trust & o & $\bullet$ & & & & \\
\hline Sanwa & $\circ$ & $\bullet$ & & & & Mitsubishi UFJ \\
\hline Tokai & $\circ$ & $\bullet$ & & & & \\
\hline Toyo Trust & $\circ$ & $\bullet$ & & & & \\
\hline Asahi & $\circ$ & $\bullet$ & & & & \\
\hline Daiwa & ○ & $\bullet$ & & & & Resona \\
\hline Kinki Osaka & & & & & $\bullet$ & \\
\hline Sumitomo Trust & ० & $\bullet$ & & & & \\
\hline Mitsui Trust & ० & $\bullet$ & & & & Mitsui Trust \\
\hline Chuo Trust & $\circ$ & $\bullet$ & & & & Mitsui Irust \\
\hline Yokohama & $\circ$ & $\bullet$ & & & & \\
\hline Hokuriku & $\circ$ & $\bullet$ & & & & Hokuhoku \\
\hline Hokkaido & & & $\bullet$ & & & \\
\hline Ashikaga & ○ & $\bullet$ & & & & Ashigin \\
\hline Shinsei & ० & & $\bullet$ & & & \\
\hline Aozora & $\circ$ & & & $\bullet$ & & \\
\hline Ryukyu & & & $\bullet$ & & & \\
\hline Hiroshima Sogo & & & $\bullet$ & & & Momiji \\
\hline Kumamoto Family & & & $\bullet$ & & & \\
\hline Chiba Kogyo & & & & $\bullet$ & & \\
\hline Yachiyo & & & & • & & \\
\hline Kansai Sawayaka & & & & $\bullet$ & & \\
\hline Higashi Nippon & & & & $\bullet$ & & \\
\hline Gifu & & & & & $\bullet$ & \\
\hline Fukuoka City & & & & & $\bullet$ & Nishi Nippon City \\
\hline Wakayama & & & & & $\bullet$ & \\
\hline Kyushu & & & & & $\bullet$ & Kyushu Shinwa \\
\hline
\end{tabular}


Table 3 Summary Statistics

\begin{tabular}{lrrrr}
\hline & Mean & Std. Dev. & Maximum & Minimum \\
\hline Internatioinal banks (FY 1993-2005) & & & & \\
$\Delta \log ($ Loan)_t $(\%)$ & 0.549 & 4.041 & 13.604 & -15.758 \\
$\Delta \log ($ SME)_t (\%) & 0.413 & 4.276 & 14.714 & -26.665 \\
Loan-Deposit interest rate spred_t (\%) & 1.377 & 0.131 & 1.557 & 1.103 \\
Capital ratio_t (\%) & 10.962 & 1.380 & 15.030 & 8.360 \\
Tier1 ratio_t (\%) & 7.354 & 1.787 & 12.166 & 4.184 \\
& & & & \\
Domestic banks (FY 1999-2005) & & & & \\
$\Delta \log ($ Loan)_t (\%) & -0.021 & 4.308 & 21.939 & -28.732 \\
$\Delta \log ($ SME)_t (\%) & -0.424 & 7.851 & 32.200 & -173.592 \\
Loan-Deposit interest rate spred_t $(\%)$ & 1.385 & 0.159 & 1.557 & 1.103 \\
Capital ratio_t $(\%)$ & 9.387 & 1.949 & 19.470 & 4.110 \\
Tier1 ratio_t $(\%)$ & 7.477 & 2.106 & 19.121 & 2.215 \\
\hline
\end{tabular}


Asia Pacific Economic Papers

Table 4 Effects of capital injections on bank lending-international banks

\begin{tabular}{|c|c|c|c|c|c|c|c|c|}
\hline \multicolumn{9}{|l|}{ Panel A Loan $=$ Total Loans } \\
\hline Ratio & \multicolumn{4}{|c|}{ Capital Ratio } & \multicolumn{4}{|c|}{ Tier1 Ratio } \\
\hline Equation No. & (1) & (2) & (3) & (4) & (1) & (2) & (3) & (4) \\
\hline \multicolumn{9}{|l|}{ Dependent Variable $: \Delta \log \left(\right.$ Loan) $\_t+1$} \\
\hline$\Delta \log ($ Loan $) \_t$ & $\begin{array}{c}0.023 \\
(0.738)\end{array}$ & $\begin{array}{l}-0.016 \\
(-0.200)\end{array}$ & $\begin{array}{r}0.002 \\
(0.055)\end{array}$ & $\begin{array}{r}-0.033 \\
(-0.428)\end{array}$ & $\begin{array}{c}-0.005 \\
(-0.142)\end{array}$ & $\begin{array}{l}-0.048 \\
(-1.205)\end{array}$ & $\begin{array}{r}-0.018 \\
(-0.361)\end{array}$ & $\begin{array}{r}-0.081 \\
(-1.161)\end{array}$ \\
\hline Loan-Deposit interest rate spred_t & $\begin{array}{l}-11.561 * * * \\
(-7.155)\end{array}$ & $\begin{array}{l}-12.810 * * * \\
(-2.621)\end{array}$ & $\begin{array}{l}-12.015 * * * \\
(-7.512)\end{array}$ & $\begin{array}{l}-13.019 * * * \\
(-4.962)\end{array}$ & $\begin{array}{l}-8.956 * * * \\
(-6.566)\end{array}$ & $\begin{array}{l}-10.097 \text { *** } \\
(-4.936)\end{array}$ & $\begin{array}{l}-10.448 \text { *** } \\
(-7.625)\end{array}$ & $\begin{array}{l}-11.529 * * * \\
(-7.496)\end{array}$ \\
\hline$\Delta \log (\mathrm{GDP}) \_\mathrm{t}+1$ & $\begin{array}{l}0.535 \text { *** } \\
(2.853)\end{array}$ & $\begin{array}{c}0.419 \\
(1.034)\end{array}$ & $\begin{array}{c}0.458 * \\
(1.906)\end{array}$ & $\begin{array}{r}0.411 \\
(1.437)\end{array}$ & $\begin{array}{l}0.784 * * * \\
(5.047)\end{array}$ & $\begin{array}{l}0.480 \\
(3.613)\end{array}$ & $\begin{array}{l}0.723 \text { *** } \\
(3.789)\end{array}$ & $\begin{array}{l}0.433 \text { *** } \\
(3.048)\end{array}$ \\
\hline$\Delta \log ($ Deposit)_t $t+1$ & & & $\begin{array}{l}0.101 \text { *** } \\
(3.733)\end{array}$ & $\begin{array}{r}0.063 \\
(0.835)\end{array}$ & & & $\begin{array}{l}0.109 \text { *** } \\
(3.583)\end{array}$ & $\begin{array}{l}0.124 \text { *** } \\
(3.292)\end{array}$ \\
\hline Capital ratio_t & $\begin{array}{c}0.140 \\
(0.309)\end{array}$ & $\begin{array}{c}0.282 \\
(0.600)\end{array}$ & $\begin{array}{r}-0.153 \\
(-0.358)\end{array}$ & $\begin{array}{r}0.127 \\
(0.214)\end{array}$ & & & & \\
\hline Tier1 ratio_t & & & & & $\begin{array}{l}0.847 \text { *** } \\
(2.752)\end{array}$ & $\begin{array}{c}0.615 \\
(1.646)\end{array}$ & $\begin{array}{l}0.872 \text { *** } \\
(2.776)\end{array}$ & $\begin{array}{r}0.556 \\
(1.373)\end{array}$ \\
\hline \multicolumn{9}{|c|}{$\begin{array}{l}\text { Effects of Capital Injection } \\
\text { (a)Total effect of two capital injection policies }\end{array}$} \\
\hline Capital ratio_t $\cdot$ InjD_t +1 & $\begin{array}{l}3.419 \text { *** } \\
(3.974)\end{array}$ & & $\begin{array}{l}2.851 \text { *** } \\
(2.862)\end{array}$ & & & & & \\
\hline Tier1 ratio_t $\cdot$ InjD_t $t+1$ & & & & & $\begin{array}{l}5.851 * * * \\
(8.793)\end{array}$ & & $\begin{array}{l}5.014 \text { *** } \\
(6.977)\end{array}$ & \\
\hline InjD_t+1 & $\begin{array}{l}-40.373 * * * \\
(-4.558)\end{array}$ & & $\begin{array}{l}-33.756 \text { *** } \\
(-3.223)\end{array}$ & & $\begin{array}{l}-38.049 * * * \\
(-9.885)\end{array}$ & & $\begin{array}{l}-32.750 \text { *** } \\
(-7.597)\end{array}$ & \\
\hline \multicolumn{9}{|l|}{ (b)Financial Function Stabilization Law } \\
\hline Capital ratio_t $t \cdot$ StabD_t $t+1$ & & $\begin{array}{l}-1.478 \\
(-0.455)\end{array}$ & & $\begin{array}{r}-1.733 \\
(-0.861)\end{array}$ & & & & \\
\hline Tier1 ratio_t $\cdot$ StabD_t +1 & & & & & & $\begin{array}{l}2.629 * \\
(1.791)\end{array}$ & & $\begin{array}{r}0.832 \\
(0.531)\end{array}$ \\
\hline StabD_t+1 & & $\begin{array}{l}19.179 \\
(0.510)\end{array}$ & & $\begin{array}{l}20.830 \\
(0.844)\end{array}$ & & $\begin{array}{l}-18.013 \\
(-1.610)\end{array}$ & & $\begin{array}{r}-6.207 \\
(-0.526)\end{array}$ \\
\hline \multicolumn{9}{|l|}{ (c)Early Strengthening Law } \\
\hline Capital ratio_t $\cdot$ EarlyD_t+1 & & $\begin{array}{l}10.937 * * * \\
(2.882)\end{array}$ & & $\begin{array}{l}10.305 * * * \\
(3.039)\end{array}$ & & & & \\
\hline Tier1 ratio_t $\cdot$ EarlyD_t+1 & & & & & & $\begin{array}{l}7.611 \text { *** } \\
(3.721)\end{array}$ & & $\begin{array}{l}7.966 * * * \\
(4.096)\end{array}$ \\
\hline EarlyD_t+1 & & $\begin{array}{c}-129.333 \text { *** } \\
(-2.712)\end{array}$ & & $\begin{array}{l}-120.680 \text { *** } \\
(-2.783)\end{array}$ & & $\begin{array}{l}-48.865 \text { *** } \\
(-2.767)\end{array}$ & & $\begin{array}{l}-52.085 * * * \\
(-3.036)\end{array}$ \\
\hline Obs. & 133 & 133 & 133 & 133 & 133 & 133 & 133 & 133 \\
\hline
\end{tabular}


No. 391, 2011

Panel B Loan $=$ SME Loans

\begin{tabular}{|c|c|c|c|c|c|c|c|c|}
\hline \multirow{2}{*}{$\begin{array}{c}\text { Ratio } \\
\text { Equation No. }\end{array}$} & \multicolumn{4}{|c|}{ Capital Ratio } & \multicolumn{4}{|c|}{ Tier1 Ratio } \\
\hline & (1) & (2) & (3) & (4) & (1) & (2) & (3) & (4) \\
\hline \multicolumn{9}{|l|}{ Dependent Variable $: \Delta \log \left(\right.$ Loan) $\_t+1$} \\
\hline$\Delta \log (\operatorname{Loan}) \_\mathrm{t}$ & $\begin{array}{c}0.008 \\
(0.217)\end{array}$ & $\begin{array}{c}-0.076 \\
(-0.399)\end{array}$ & $\begin{array}{r}0.013 \\
(0.336)\end{array}$ & $\begin{array}{r}-0.077 \\
(-0.410)\end{array}$ & $\begin{array}{c}-0.053 \\
(-1.140)\end{array}$ & $\begin{array}{c}-0.214 \\
(-0.832)\end{array}$ & $\begin{array}{l}-0.060 \\
(-1.108)\end{array}$ & $\begin{array}{c}-0.126 \\
(-0.565)\end{array}$ \\
\hline Loan-Deposit interest rate spred_t & $\begin{array}{l}-7.857 \text { *** } \\
(-11.323)\end{array}$ & $\begin{array}{l}-7.203 \text { *** } \\
(-2.667)\end{array}$ & $\begin{array}{l}-8.052 * * * \\
(-9.740)\end{array}$ & $\begin{array}{l}-7.327 \text { ** } \\
(-2.515)\end{array}$ & $\begin{array}{l}-7.651 * * * \\
(-4.506)\end{array}$ & $\begin{array}{l}-9.096 * * * \\
(-3.286)\end{array}$ & $\begin{array}{l}-8.437 * * * \\
(-6.524)\end{array}$ & $\begin{array}{l}-9.019 * * * \\
(-4.538)\end{array}$ \\
\hline$\Delta \log (\mathrm{GDP}) \_\mathrm{t}+1$ & $\begin{array}{l}0.498 \text { *** } \\
(3.242)\end{array}$ & $\begin{array}{c}-0.031 \\
(-0.073)\end{array}$ & $\begin{array}{l}0.532 * * \\
(2.469)\end{array}$ & $\begin{array}{r}-0.044 \\
(-0.092)\end{array}$ & $\begin{array}{c}0.512 \\
(1.227)\end{array}$ & $\begin{array}{c}-0.048 \\
(-0.091)\end{array}$ & $\begin{array}{c}0.572 \\
(1.519)\end{array}$ & $\begin{array}{c}0.136 \\
(0.383)\end{array}$ \\
\hline$\Delta \log ($ Deposit)_t+1 & & & $\begin{array}{l}0.088 * * * \\
(5.976)\end{array}$ & $\begin{array}{r}0.000 \\
(0.000)\end{array}$ & & & $\begin{array}{l}0.102 \text { *** } \\
(2.779)\end{array}$ & $\begin{array}{c}0.043 \\
(0.971)\end{array}$ \\
\hline Capital ratio_t & $\begin{array}{l}0.388 * * \\
(2.270)\end{array}$ & $\begin{array}{c}0.027 \\
(0.042)\end{array}$ & $\begin{array}{l}0.435 * \\
(1.972)\end{array}$ & $\begin{array}{r}0.013 \\
(0.029)\end{array}$ & & & & \\
\hline Tier1 ratio_t & & & & & $\begin{array}{c}0.744 \\
(1.146)\end{array}$ & $\begin{array}{c}0.006 \\
(0.006)\end{array}$ & $\begin{array}{c}0.832 \\
(1.449)\end{array}$ & $\begin{array}{c}0.250 \\
(0.399)\end{array}$ \\
\hline \multicolumn{9}{|c|}{$\begin{array}{l}\text { Effects of Capital Injection } \\
\text { (a)Total effect of two capital injection policies }\end{array}$} \\
\hline Capital ratio_t $\cdot$ InjD_t+1 & $\begin{array}{l}2.717 \text { *** } \\
(3.597)\end{array}$ & & $\begin{array}{l}2.513 * * * \\
(2.811)\end{array}$ & & & & & \\
\hline Tier1 ratio_t $\cdot$ InjD_t $t+1$ & & & & & $\begin{array}{l}2.528 * * \\
(2.201)\end{array}$ & & $\begin{array}{c}2.301 \\
(1.406)\end{array}$ & \\
\hline InjD_t+1 & $\begin{array}{l}-27.622 * * * \\
(-3.429)\end{array}$ & & $\begin{array}{l}-25.456 * * * \\
(-2.747)\end{array}$ & & $\begin{array}{l}-12.863 * \\
(-1.785)\end{array}$ & & $\begin{array}{l}-10.896 \\
(-1.126)\end{array}$ & \\
\hline \multicolumn{9}{|l|}{ (b)Financial Function Stabilization Law } \\
\hline Capital ratio_t $\cdot$ StabD_t $t+1$ & & $\begin{array}{c}7.540 \\
(0.827)\end{array}$ & & $\begin{array}{r}7.231 \\
(0.834)\end{array}$ & & & & \\
\hline Tier1 ratio_t $\cdot$ StabD_t $t+1$ & & & & & & $\begin{array}{l}-14.160 \\
(-0.361)\end{array}$ & & $\begin{array}{l}-2.494 \\
(-0.124)\end{array}$ \\
\hline StabD_t+1 & & $\begin{array}{l}-86.778 \\
(-0.975)\end{array}$ & & $\begin{array}{l}-83.764 \\
(-0.913)\end{array}$ & & $\begin{array}{l}65.119 \\
(0.327)\end{array}$ & & $\begin{array}{c}4.074 \\
(0.042)\end{array}$ \\
\hline \multicolumn{9}{|l|}{ (c)Early Strengthening Law } \\
\hline Capital ratio_t $\cdot$ EarlyD_t+1 & & $\begin{array}{l}-6.164 \\
(-0.495)\end{array}$ & & $\begin{array}{r}-5.857 \\
(-0.435)\end{array}$ & & & & \\
\hline Tier1 ratio_t $\cdot$ EarlyD_t+1 & & & & & & $\begin{array}{l}20.430 \\
(0.474)\end{array}$ & & $\begin{array}{c}7.306 \\
(0.355)\end{array}$ \\
\hline EarlyD_t+1 & & $\begin{array}{l}76.550 \\
(0.551)\end{array}$ & & $\begin{array}{l}73.397 \\
(0.476)\end{array}$ & & $\begin{array}{r}-103.739 \\
(-0.450)\end{array}$ & & $\begin{array}{l}-30.318 \\
(-0.295)\end{array}$ \\
\hline Obs. & 131 & 131 & 131 & 131 & 131 & 131 & 131 & 131 \\
\hline
\end{tabular}

I t-statistics in parentheses; *Significant at $10 \% ; * *$ significant at $5 \% ; * * *$ significant at $1 \%$

2 Method : Panel Generalized Method of Moments (Arellano and Bover [1995])

*3 The unit of $\Delta \log ($ Loan), Loan-Deposit interest rate spred, Capital ratio and Tier 1 ratio is \%

*4 The results reported are for the sample FY 1993-2006

* 5 In the case of using equation (1) and (3), we examine the total effect of two capital injection policies: the Financial Function Stabilization Law and the Early Strengthening Law.

On the other hand, using equation (2) and (4), we separately examine the each effects of these two laws. 
Asia Pacific Economic Papers

Table 5 Effects of capital injections on bank lending-domestic banks

Panel A Loan $=$ Total Loans

\begin{tabular}{|c|c|c|c|c|c|c|c|c|}
\hline \multirow{2}{*}{$\begin{array}{c}\text { Ratio } \\
\text { Equation No. }\end{array}$} & \multicolumn{4}{|c|}{ Capital Ratio } & \multicolumn{4}{|c|}{ Tier1 Ratio } \\
\hline & (1) & (2) & (3) & (4) & (1) & (2) & (3) & (4) \\
\hline \multicolumn{9}{|l|}{ Dependent Variable $: \Delta \log \left(\right.$ Loan) $\_t+1$} \\
\hline$\Delta \log ($ Loan $) \_t$ & $\begin{array}{c}-0.034 \\
(-1.523)\end{array}$ & $\begin{array}{c}0.031 \\
(1.136)\end{array}$ & $\begin{array}{c}-0.023 \\
(-1.222)\end{array}$ & $\begin{array}{c}0.036 \\
(1.905)\end{array}$ & $\begin{array}{c}-0.027 \\
(-1.363)\end{array}$ & $\begin{array}{c}0.033 * \\
(1.649)\end{array}$ & $\begin{array}{c}-0.028 \\
(-1.275)\end{array}$ & $\begin{array}{l}0.041 * * \\
(2.544)\end{array}$ \\
\hline Loan-Deposit interest rate spred_t & $\begin{array}{l}-1.590 * \\
(-1.802)\end{array}$ & $\begin{array}{l}-1.905 * * \\
(-2.432)\end{array}$ & $\begin{array}{l}-1.902 * * \\
(-2.563)\end{array}$ & $\begin{array}{l}-2.539 * * * \\
(-4.239)\end{array}$ & $\begin{array}{l}-1.057 \\
(-1.270)\end{array}$ & $\begin{array}{l}-1.527 * \\
(-1.794)\end{array}$ & $\begin{array}{l}-1.607 * * \\
(-2.202)\end{array}$ & $\begin{array}{l}-1.868 * * * \\
(-2.811)\end{array}$ \\
\hline$\Delta \log (\mathrm{GDP}) \_\mathrm{t}+1$ & $\begin{array}{l}0.362 \text { *** } \\
(8.074)\end{array}$ & $\begin{array}{l}0.409 \text { *** } \\
(7.572)\end{array}$ & $\begin{array}{l}0.341 \text { *** } \\
(7.804)\end{array}$ & $\begin{array}{l}0.365 * * * \\
(7.331)\end{array}$ & $\begin{array}{l}0.398 \text { *** } \\
(6.476)\end{array}$ & $\begin{array}{l}0.427 \text { *** } \\
(8.830)\end{array}$ & $\begin{array}{l}0.381 \text { *** } \\
(7.858)\end{array}$ & $\begin{array}{l}0.358 \text { *** } \\
(6.477)\end{array}$ \\
\hline$\Delta \log ($ Deposit $) \_t+1$ & & & $\begin{array}{l}0.3011^{* * * *} \\
(10.698)\end{array}$ & $\begin{array}{l}0.302 \text { *** } \\
(11.136)\end{array}$ & & & $\begin{array}{l}0.298 \text { *** } \\
(12.349)\end{array}$ & $\begin{array}{l}0.314 \text { *** } \\
(12.362)\end{array}$ \\
\hline Capital ratio_t & $\begin{array}{l}0.757 \text { *** } \\
(3.231)\end{array}$ & $\begin{array}{l}0.374 * * \\
(1.970)\end{array}$ & $\begin{array}{l}0.609 * * * \\
(2.933)\end{array}$ & $\begin{array}{c}0.111 \\
(0.727)\end{array}$ & & & & \\
\hline Tierl ratio_t & & & & & $\begin{array}{l}1.199 * * * \\
(3.949)\end{array}$ & $\begin{array}{l}0.744 * * * \\
(2.629)\end{array}$ & $\begin{array}{l}0.9344^{* * *} \\
(3.212)\end{array}$ & $\begin{array}{l}0.508 * * \\
(1.951)\end{array}$ \\
\hline \multicolumn{9}{|c|}{$\begin{array}{l}\text { Effects of Capital Injection } \\
\text { (a)Total effect of two capital injection policies }\end{array}$} \\
\hline Capital ratio_t $\cdot$ InjD_t $t+1$ & $\begin{array}{l}0.813 * * * \\
(2.797)\end{array}$ & & $\begin{array}{l}0.746 \text { ** } \\
(2.388)\end{array}$ & & & & & \\
\hline Tier1 ratio_t $\cdot$ InjD_t $t+1$ & & & & & $\begin{array}{c}0.467 \\
(1.184)\end{array}$ & & $\begin{array}{l}0.630 * * \\
(1.969)\end{array}$ & \\
\hline InjD_t+1 & $\begin{array}{l}-14.548 * * * \\
(-5.328)\end{array}$ & & $\begin{array}{l}-11.392 \text { **** } \\
(-3.761)\end{array}$ & & $\begin{array}{l}-10.462 \text { *** } \\
(-2.870)\end{array}$ & & $\begin{array}{l}-8.416 \text { *** } \\
(-3.162)\end{array}$ & \\
\hline \multicolumn{9}{|l|}{ (b)Financial Function Stabilization Law } \\
\hline Capital ratio_t $\cdot$ StabD_t+1 & & $\begin{array}{l}3.378 \text { *** } \\
(15.766)\end{array}$ & & $\begin{array}{l}3.276 \text { *** } \\
(14.653)\end{array}$ & & & & \\
\hline Tier1 ratio_t $\cdot$ StabD_t $t+1$ & & & & & & $\begin{array}{l}3.569 \text { *** } \\
(12.684)\end{array}$ & & $\begin{array}{l}3.882 \text { *** } \\
(13.316)\end{array}$ \\
\hline StabD_t+1 & & $\begin{array}{l}-38.698 * * * \\
(-14.791)\end{array}$ & & $\begin{array}{l}-38.720 * * * \\
(-16.757)\end{array}$ & & $\begin{array}{l}-30.545 \text { *** } \\
(-8.135)\end{array}$ & & $\begin{array}{l}-30.828 \text { *** } \\
(-9.315)\end{array}$ \\
\hline \multicolumn{9}{|l|}{ (c)Early Strengthening Law } \\
\hline Capital ratio_t $\cdot$ EarlyD_t $t+1$ & & $\begin{array}{l}-0.920 * * * \\
(-4.775)\end{array}$ & & $\begin{array}{l}-0.771 * * * \\
(-4.173)\end{array}$ & & & & \\
\hline Tier1 ratio_t $\cdot$ EarlyD_t $t+1$ & & & & & & $\begin{array}{l}-1.518 * * * \\
(-5.391)\end{array}$ & & $\begin{array}{l}-1.665 \text { *** } \\
(-5.838)\end{array}$ \\
\hline EarlyD_t+1 & & $\begin{array}{c}0.340 \\
(0.153)\end{array}$ & & $\begin{array}{c}2.217 \\
(1.259)\end{array}$ & & $\begin{array}{c}3.038 \\
(1.199)\end{array}$ & & $\begin{array}{l}6.944 * * * \\
(2.928)\end{array}$ \\
\hline Obs. & 557 & 557 & 557 & 557 & 556 & 556 & 556 & 556 \\
\hline
\end{tabular}


No. 391, 2011

\section{Panel B}

Loan $=$ SME Loans

\begin{tabular}{|c|c|c|c|c|c|c|c|c|}
\hline \multirow{2}{*}{$\begin{array}{c}\text { Ratio } \\
\text { Equation No. }\end{array}$} & \multicolumn{4}{|c|}{ Capital Ratio } & \multicolumn{4}{|c|}{ Tier1 Ratio } \\
\hline & (1) & (2) & (3) & (4) & (1) & (2) & (3) & (4) \\
\hline \multicolumn{9}{|l|}{ Dependent Variable : $\triangle \log \left(\right.$ Loan) $\_t+1$} \\
\hline$\Delta \log (\operatorname{Loan}) \_\mathrm{t}$ & $\begin{array}{c}-0.017 \\
(-1.151)\end{array}$ & $\begin{array}{l}-0.028 * \\
(-1.716)\end{array}$ & $\begin{array}{c}-0.016 \\
(-0.928)\end{array}$ & $\begin{array}{l}-0.042 * * \\
(-2.502)\end{array}$ & $\begin{array}{l}-0.043 * * * * \\
(-3.201)\end{array}$ & $\begin{array}{l}-0.050 * * * \\
(-2.780)\end{array}$ & $\begin{array}{l}-0.041 \text { *** } \\
(-3.087)\end{array}$ & $\begin{array}{l}-0.069 * * * \\
(-4.091)\end{array}$ \\
\hline Loan-Deposit interest rate spred_t & $\begin{array}{l}1.692 * \\
(1.726)\end{array}$ & $\begin{array}{c}1.373 \\
(1.518)\end{array}$ & $\begin{array}{c}1.069 \\
(1.231)\end{array}$ & $\begin{array}{c}0.312 \\
(0.383)\end{array}$ & $\begin{array}{l}3.231 * * * \\
(6.094)\end{array}$ & $\begin{array}{l}2.718 \text { *** } \\
(3.967)\end{array}$ & $\begin{array}{l}2.938 \text { *** } \\
(4.924)\end{array}$ & $\begin{array}{l}2.004 \text { *** } \\
(2.670)\end{array}$ \\
\hline$\Delta \log (\mathrm{GDP}) \_\mathrm{t}+1$ & $\begin{array}{l}0.805 \text { *** } \\
(14.663)\end{array}$ & $\begin{array}{l}0.746 * * * \\
(16.623)\end{array}$ & $\begin{array}{l}0.769 * * * \\
(12.627)\end{array}$ & $\begin{array}{l}0.705 * * * \\
(14.252)\end{array}$ & $\begin{array}{l}0.763 * * * \\
(13.633)\end{array}$ & $\begin{array}{l}0.720 \text { *** } \\
(11.969)\end{array}$ & $\begin{array}{l}0.731 \text { **** } \\
(12.660)\end{array}$ & $\begin{array}{l}0.641 \text { *** } \\
(11.882)\end{array}$ \\
\hline$\Delta \log ($ Deposit $) \_t+1$ & & & $\begin{array}{l}0.265 * * * \\
(13.277)\end{array}$ & $\begin{array}{l}0.284 * * * \\
(12.678)\end{array}$ & & & $\begin{array}{l}0.271 * * * \\
(14.546)\end{array}$ & $\begin{array}{l}0.312 \\
(13.299)\end{array}$ \\
\hline Capital ratio_t & $\begin{array}{l}0.683 * * \\
(2.255)\end{array}$ & $\begin{array}{c}0.319 \\
(1.380)\end{array}$ & $\begin{array}{l}0.542 * * \\
(2.088)\end{array}$ & $\begin{array}{l}-0.040 \\
(-0.205)\end{array}$ & & & & \\
\hline Tier1 ratio_t & & & & & $\begin{array}{l}1.587 * * * \\
(8.399)\end{array}$ & $\begin{array}{l}1.228 * * * \\
(4.062)\end{array}$ & $\begin{array}{l}1.381 * * * \\
(7.567)\end{array}$ & $\begin{array}{l}0.655 * * \\
(2.415)\end{array}$ \\
\hline \multicolumn{9}{|c|}{$\begin{array}{l}\text { Effects of Capital Injection } \\
\text { (a)Total effect of two capital injection policies }\end{array}$} \\
\hline Capital ratio_t $\cdot$ InjD_t $t+1$ & $\begin{array}{l}3.129 * * * \\
(8.758)\end{array}$ & & $\begin{array}{l}2.982 * * * \\
(8.994)\end{array}$ & & & & & \\
\hline Tier1 ratio_t $\cdot$ InjD_t $t+1$ & & & & & $\begin{array}{l}2.303 \text { **** } \\
(10.170)\end{array}$ & & $\begin{array}{l}2.419^{\text {**** }} \\
(8.882)\end{array}$ & \\
\hline InjD_t+1 & $\begin{array}{l}-29.302 * * * \\
(-7.994)\end{array}$ & & $\begin{array}{l}-24.5411^{* * *} \\
(-7.631)\end{array}$ & & $\begin{array}{l}-15.833 * * * \\
(-7.731)\end{array}$ & & $\begin{array}{l}-12.453 \text { *** } \\
(-6.611)\end{array}$ & \\
\hline \multicolumn{9}{|l|}{ (b)Financial Function Stabilization Law } \\
\hline Capital ratio_t $\mathrm{t} \cdot \mathrm{StabD} \_\mathrm{t}+1$ & & $\begin{array}{l}5.898 \text { *** } \\
(22.722)\end{array}$ & & $\begin{array}{l}5.913 \text { *** } \\
(22.515)\end{array}$ & & & & \\
\hline Tier1 ratio_t $\cdot$ StabD_t +1 & & & & & & $\begin{array}{l}5.785 * * * \\
(16.099)\end{array}$ & & $\begin{array}{l}6.541 \text { **** } \\
(24.396)\end{array}$ \\
\hline StabD_t+1 & & $\begin{array}{l}-69.683 * * * \\
(-14.727)\end{array}$ & & $\begin{array}{l}-72.520 * * * \\
(-15.799)\end{array}$ & & $\begin{array}{l}-51.628 * * * \\
(-5.817)\end{array}$ & & $\begin{array}{l}-58.579 * * * \\
(-8.581)\end{array}$ \\
\hline \multicolumn{9}{|l|}{ (c)Early Strengthening Law } \\
\hline Capital ratio_t $\cdot$ EarlyD_t $t+1$ & & $\begin{array}{l}-0.194 \\
(-0.655)\end{array}$ & & $\begin{array}{c}-0.083 \\
(-0.321)\end{array}$ & & & & \\
\hline Tier1 ratio_t $\cdot$ EarlyD_t+1 & & & & & & $\begin{array}{l}-1.421 \text { *** } \\
(-4.014)\end{array}$ & & $\begin{array}{l}-1.419 * * * \\
(-5.081)\end{array}$ \\
\hline EarlyD_t+1 & & $\begin{array}{c}0.600 \\
(0.224)\end{array}$ & & $\begin{array}{l}3.925 * \\
(1.734)\end{array}$ & & $\begin{array}{l}8.500 * * * \\
(3.642)\end{array}$ & & $\begin{array}{l}12.573 \text { *** } \\
(5.945)\end{array}$ \\
\hline Obs. & 549 & 549 & 549 & 549 & 548 & 548 & 548 & 548 \\
\hline
\end{tabular}

$* 1$ t-statistics in parentheses; $*$ Significant at $10 \% ; * *$ significant at $5 \% ; * * *$ significant at $1 \%$

*2 Method : Panel Generalized Method of Moments (Arellano and Bover [1995])

*3 The unit of $\triangle \log (\operatorname{Loan})$, Loan-Deposit interest rate spred, Capital ratio and Tier 1 ratio is \%

*4 The results reported are for the sample FY 1999-2006

*5 In the case of using equation (1) and (3), we examine the total effect of two capital injection policies: the Financial Function Stabilization Law and the Early Strengthening Law. On the other hand, using equation (2) and (4), we separately examine the each effects of these two laws. 


\section{Appendix: Robustness Check-Endogeneity of the Interest Rate}

In our analysis, we assumed that the differential between loan and deposit interest rates is exogenous. However, it is also plausible that interest rates are assumed to be endogenous. So, in order to check the robustness of our results, we will use $r_{i, t}^{L}-r_{i, t}^{D}$ in place of $r_{t}^{L}-r_{t}^{D}$ to estimate the following equations: (1)'-(4)';

$$
\begin{aligned}
& \Delta \log \left(L_{i, t+1}\right)=\alpha_{0}+\alpha_{1} \Delta \log \left(L_{i, t}\right)+\beta_{1} \operatorname{Cap}_{i, t}+\gamma_{1}\left(r_{i, t}^{L}-r_{i, t}^{D}\right)+\gamma_{2} \Delta \log \left(G D P_{t+1}\right) \\
& +\beta_{2} \operatorname{Cap}_{i, t} \cdot \operatorname{Inj} D_{i, t+1}+\delta_{1} \operatorname{Inj} D_{i, t+1}+\varepsilon_{i, t+1} \\
& \Delta \log \left(L_{i, t+1}\right)=\alpha_{0}+\alpha_{1} \Delta \log \left(L_{i, t}\right)+\beta_{1} \operatorname{Cap}_{i, t}+\gamma_{1}\left(r_{i, t}^{L}-r_{i, t}^{D}\right)+\gamma_{2} \Delta \log \left(G D P_{t+1}\right) \\
& +\beta_{3} \operatorname{Cap}_{i, t} \cdot \operatorname{StabD}_{i, t+1}+\delta_{2} \operatorname{StabD}_{i, t+1}+\beta_{4} \operatorname{Cap}_{i, t} \cdot \operatorname{Early}_{i, t+1}+\delta_{3} \operatorname{Early}_{i, t+1} \\
& +\varepsilon_{i, t+1}(2)^{\prime}
\end{aligned}
$$

$$
\begin{aligned}
\Delta \log \left(L_{i, t+1}\right)= & \alpha_{0}+\alpha_{1} \Delta \log \left(L_{i, t}\right)+\beta_{1} \operatorname{Cap}_{i, t}+\gamma_{1}\left(r_{i, t}^{L}-r_{i, t}^{D}\right)+\gamma_{2} \Delta \log \left(G D P_{t+1}\right) \\
& +\gamma_{3} \Delta \log \left(\text { Deposit }_{i, t+1}\right)+\beta_{2} \operatorname{Cap}_{i, t} \cdot \operatorname{Inj}_{i, t+1}+\delta_{1} \operatorname{Inj} D_{i, t+1}+\varepsilon_{i, t+1}
\end{aligned}
$$

$$
\begin{array}{r}
\Delta \log \left(L_{i, t+1}\right)=\alpha_{0}+\alpha_{1} \Delta \log \left(L_{i, t}\right)+\beta_{1} \operatorname{Cap}_{i, t}+\gamma_{1}\left(r_{i, t}^{L}-r_{i, t}^{D}\right)+\gamma_{2} \Delta \log \left(G D P_{t+1}\right) \\
+\gamma_{3} \Delta \log \left(\text { Deposit }_{i, t+1}\right)+\beta_{3} \operatorname{Cap}_{i, t} \cdot \operatorname{StabD}_{i, t+1}+\delta_{2} \operatorname{StabD}_{i, t+1} \\
+\beta_{4} \operatorname{Cap}_{i, t} \cdot \operatorname{Early}_{i, t+1}+\delta_{3} \operatorname{Early}_{i, t+1}+\varepsilon_{i, t+1}
\end{array}
$$


No. 391, 2011

As with original equations, these four equations are estimated with the Arellano and Bover (1995) procedure (GMM). As for $r_{i, t}^{L}$ and $r_{i, t}^{D}$, we calculate them using the following equation;

$$
\begin{aligned}
& \mathrm{r}_{\mathrm{i}, \mathrm{t}}^{\mathrm{L}}=\frac{\left.\prime \text { Interste on Loans \& Bills Discounted } \mathrm{d}^{\prime} \text { (reported on the income statement of bank i in FY } \mathrm{t}\right)}{\text { LLoans \& Bills Discounted }^{\prime}(\text { on the asset side of the balance sheet of bank } \mathrm{i} \text { in FY } \mathrm{t})}
\end{aligned}
$$

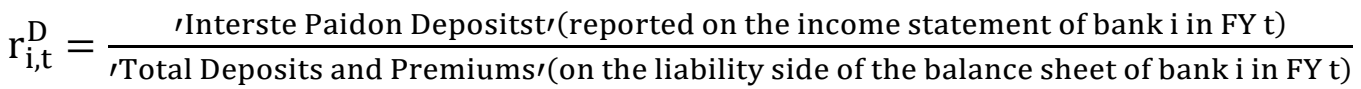

Estimation results for international banks and domestic banks are presented in Table 6 and 7 respectively. Comparing these results with those of Table 4 and 5, there is almost no big difference among them. The robustness of our research has checked and shown. 
Asia Pacific Economic Papers

Table 6 Robustness Check-international banks

\begin{tabular}{|c|c|c|c|c|c|c|c|c|}
\hline \multirow{2}{*}{$\begin{array}{c}\text { Ratio } \\
\text { Equation No. }\end{array}$} & \multicolumn{4}{|c|}{ Capital Ratio } & \multicolumn{4}{|c|}{ Tier1 Ratio } \\
\hline & & & & & & & & \\
\hline \multirow{2}{*}{\multicolumn{9}{|c|}{ Dependent Variable $: \Delta \log ($ Loan)_t $t+1$}} \\
\hline$\Delta \log ($ Loan)_t & $0.121 * *$ & 0.056 & & & & & & \\
\hline & $(2.046)$ & $(0.683)$ & $(0.530)$ & $(0.512)$ & $(0.559)$ & $(-0.221)$ & $(0.273)$ & $(-0.449)$ \\
\hline Loan-Deposit interest rate spred_it & $\begin{array}{l}2.408 * \\
(1.666)\end{array}$ & $\begin{array}{c}2.049 \\
(0.951)\end{array}$ & $\begin{array}{l}-1.828 \\
(-0.521)\end{array}$ & $\begin{array}{c}0.699 \\
(0.225)\end{array}$ & $\begin{array}{c}1.043 \\
(0.440)\end{array}$ & $\begin{array}{c}-0.353 \\
(-0.122)\end{array}$ & $\begin{array}{c}-1.617 \\
(-0.347)\end{array}$ & $\begin{array}{c}0.518 \\
(0.139)\end{array}$ \\
\hline$\Delta \log (\mathrm{GDP}) \_\mathrm{t}+1$ & $\begin{array}{l}0.629 * * * \\
(3.021)\end{array}$ & $\begin{array}{l}0.492 * \\
(1.706)\end{array}$ & $\begin{array}{l}0.281 \\
(0.807)\end{array}$ & $\begin{array}{c}0.358 \\
(1.064)\end{array}$ & $\begin{array}{l}0.792 * * \\
(2.451)\end{array}$ & $\begin{array}{r}0.379 \\
(1.066)\end{array}$ & $\begin{array}{r}0.363 \\
(0.657)\end{array}$ & $\begin{array}{c}0.478 \\
(0.829)\end{array}$ \\
\hline$\Delta \log ($ Deposit)_t+1 & & & $\begin{array}{c}-0.128 \\
(-0.569)\end{array}$ & $\begin{array}{c}-0.042 \\
(-0.357)\end{array}$ & & & $\begin{array}{c}-0.053 \\
(-0.537)\end{array}$ & $\begin{array}{c}0.084 \\
(0.729)\end{array}$ \\
\hline Capital ratio_t & $\begin{array}{l}-0.293 * \\
(-1.744)\end{array}$ & $\begin{array}{c}-0.168 \\
(-0.971)\end{array}$ & $\begin{array}{l}-0.539 * \\
(-1.688)\end{array}$ & $\begin{array}{c}-0.267 \\
(-1.281)\end{array}$ & & & & \\
\hline Tier1 ratio_t & & & & & $\begin{array}{l}0.707 \text { *** } \\
(2.832)\end{array}$ & $\begin{array}{l}0.479 * \\
(1.802)\end{array}$ & $\begin{array}{c}0.469 \\
(1.136)\end{array}$ & $\begin{array}{c}0.555 \\
(1.420)\end{array}$ \\
\hline \multicolumn{9}{|c|}{$\begin{array}{l}\text { Effects of Capital Injection } \\
\text { (a)Total effect of two capital iniection policies }\end{array}$} \\
\hline Capital ratio_t $\cdot$ InjD_t +1 & $\begin{array}{l}3.116 * * * \\
(3.192)\end{array}$ & & $\begin{array}{c}6.505 \\
(1.517)\end{array}$ & & & & & \\
\hline Tier1 ratio_t $\cdot$ InjD_t +1 & & & & & $\begin{array}{l}5.447 \text { *** } \\
(11.448)\end{array}$ & & $\begin{array}{l}5.881 \text { *** } \\
(4.495)\end{array}$ & \\
\hline InjD_t+1 & $\begin{array}{l}-37.499 * * * \\
(-3.781)\end{array}$ & & $\begin{array}{c}-72.552 \\
(-1.627)\end{array}$ & & $\begin{array}{l}-36.019 * * * \\
(-13.107)\end{array}$ & & $\begin{array}{l}-38.823 * * * \\
(-5.052)\end{array}$ & \\
\hline \multicolumn{9}{|l|}{ (b)Financial Function Stabilization Law } \\
\hline Capital ratio_t $\cdot$ StabD_t $t+1$ & & $\begin{array}{c}-0.311 \\
(-0.195)\end{array}$ & & $\begin{array}{c}0.106 \\
(0.054)\end{array}$ & & & & \\
\hline Tier1 ratio_t $\cdot$ StabD_t +1 & & & & & & $\begin{array}{l}2.758 * \\
(1.759)\end{array}$ & & $\begin{array}{c}2.316 \\
(1.497)\end{array}$ \\
\hline StabD_t+1 & & $\begin{array}{c}-2.135 \\
(-0.112)\end{array}$ & & $\begin{array}{c}-6.778 \\
(-0.290)\end{array}$ & & $\begin{array}{l}-24.133 \\
(-1.585)\end{array}$ & & $\begin{array}{l}-22.429 \\
(-1.518)\end{array}$ \\
\hline \multicolumn{9}{|l|}{ (c)Early Strengthening Law } \\
\hline Capital ratio_ $t \cdot$ EarlyD_t $t+1$ & & $\begin{array}{l}7.930 * * * \\
(4.389)\end{array}$ & & $\begin{array}{l}8.479^{* * * *} \\
(3.869)\end{array}$ & & & & \\
\hline Tier1 ratio_t $\cdot$ EarlyD_t +1 & & & & & & $\begin{array}{l}5.938 * * * \\
(2.762)\end{array}$ & & $\begin{array}{l}5.627 \text { ** } \\
(2.444)\end{array}$ \\
\hline EarlyD_t+1 & & $\begin{array}{l}-85.657 * * * \\
(-3.503)\end{array}$ & & $\begin{array}{l}-91.109 \text { *** } \\
(-3.209)\end{array}$ & & $\begin{array}{l}-32.624 \\
(-1.463)\end{array}$ & & $\begin{array}{l}-29.580 \\
(-1.272)\end{array}$ \\
\hline Obs. & 133 & 133 & 133 & 133 & 133 & 133 & 133 & 133 \\
\hline
\end{tabular}


No. 391, 2011

Loan =SME Loans

\begin{tabular}{|c|c|c|c|c|c|c|c|c|}
\hline \multirow{2}{*}{$\begin{array}{c}\text { Ratio } \\
\text { Equation No. } \\
\end{array}$} & \multicolumn{4}{|c|}{ Capital Ratio } & \multicolumn{4}{|c|}{ Tier1 Ratio } \\
\hline & $(1)^{\prime}$ & $(2)^{\prime}$ & $(3)^{\prime}$ & (4)' & $(1)^{\prime}$ & (2)' & $(3)^{\prime}$ & (4)' \\
\hline \multicolumn{9}{|l|}{ Dependent Variable $: \triangle \log (\operatorname{Loan}) \_t+1$} \\
\hline$\Delta \log ($ Loan $) \_t$ & $\begin{array}{c}0.031 \\
(0.543)\end{array}$ & $\begin{array}{c}0.020 \\
(0.202)\end{array}$ & $\begin{array}{c}0.046 \\
(0.555)\end{array}$ & $\begin{array}{c}0.015 \\
(0.162)\end{array}$ & $\begin{array}{c}0.018 \\
(0.291)\end{array}$ & $\begin{array}{c}-0.080 \\
(-0.435)\end{array}$ & $\begin{array}{c}0.032 \\
0.468601\end{array}$ & $\begin{array}{c}-0.058 \\
(-0.309)\end{array}$ \\
\hline Loan-Deposit interest rate spred_it & $\begin{array}{l}3.364^{* * *} \\
(2.807)\end{array}$ & $\begin{array}{l}3.556 * * \\
(2.546)\end{array}$ & $\begin{array}{l}5.221 * * \\
(2.576)\end{array}$ & $\begin{array}{c}2.374 \\
(0.819)\end{array}$ & $\begin{array}{l}2.554 * * \\
(2.345)\end{array}$ & $\begin{array}{c}2.049 \\
(1.095)\end{array}$ & $\begin{array}{c}2.878 \\
1.43149\end{array}$ & $\begin{array}{c}2.012 \\
(0.672)\end{array}$ \\
\hline$\Delta \log (\mathrm{GDP}) \_\mathrm{t}+1$ & $\begin{array}{l}0.825 * * * \\
(2.674)\end{array}$ & $\begin{array}{c}0.520 \\
(1.290)\end{array}$ & $\begin{array}{l}1.137 \text { *** } \\
(2.793)\end{array}$ & $\begin{array}{c}0.373 \\
(0.928)\end{array}$ & $\begin{array}{l}0.804 \text { **** } \\
(3.402)\end{array}$ & $\begin{array}{c}0.291 \\
(0.543)\end{array}$ & $\begin{array}{c}0.724 * \\
1.844301\end{array}$ & $\begin{array}{c}0.226 \\
(0.470)\end{array}$ \\
\hline$\Delta \log ($ Deposit)_t+1 & & & $\begin{array}{c}0.123 \\
(1.587)\end{array}$ & $\begin{array}{c}-0.028 \\
(-0.313)\end{array}$ & & & $\begin{array}{c}0.085 \\
1.241897\end{array}$ & $\begin{array}{c}0.047 \\
(0.372)\end{array}$ \\
\hline Capital ratio_t & $\begin{array}{c}0.231 \\
(1.617)\end{array}$ & $\begin{array}{c}0.087 \\
(0.392)\end{array}$ & $\begin{array}{c}0.258 \\
(1.097)\end{array}$ & $\begin{array}{c}0.051 \\
(0.249)\end{array}$ & & & & \\
\hline Tier1 ratio_t & & & & & $\begin{array}{l}1.008 * * * \\
(4.815)\end{array}$ & $\begin{array}{l}0.700 * \\
(1.921)\end{array}$ & $\begin{array}{l}0.894^{* * *} \\
3.765262\end{array}$ & $\begin{array}{l}0.686 * \\
(2.033)\end{array}$ \\
\hline \multicolumn{9}{|c|}{$\begin{array}{l}\text { Effects of Capital Injection } \\
\text { (a)Total effect of two capital injection policies }\end{array}$} \\
\hline Capital ratio_t $\cdot$ InjD_t $t+1$ & $\begin{array}{c}1.684 \\
(1.086)\end{array}$ & & $\begin{array}{c}1.212 \\
(0.533)\end{array}$ & & & & & \\
\hline Tier1 ratio_t $\cdot$ InjD_t +1 & & & & & $\begin{array}{c}2.171 \\
(1.569)\end{array}$ & & $\begin{array}{c}1.482 \\
1.268709\end{array}$ & \\
\hline InjD_t+1 & $\begin{array}{l}-16.276 \\
(-1.040)\end{array}$ & & $\begin{array}{l}-10.775 \\
(-0.462)\end{array}$ & & $\begin{array}{l}-11.020 \\
(-1.454)\end{array}$ & & $\begin{array}{c}-7.493 \\
-1.08359\end{array}$ & \\
\hline $\begin{array}{l}\text { (b)Financial Function Stabilization Law } \\
\text { Capital ratio_t } t \cdot \text { StabD_t } t+1\end{array}$ & & $\begin{array}{c}-1.709 \\
(-0.150)\end{array}$ & & $\begin{array}{c}-3.404 \\
(-0.320)\end{array}$ & & & & \\
\hline Tier1 ratio_t $\cdot$ StabD_t+1 & & & & & & $\begin{array}{l}-16.242 \\
(-1.189)\end{array}$ & & $\begin{array}{l}-15.511 \\
(-0.968)\end{array}$ \\
\hline StabD_t+1 & & $\begin{array}{l}11.965 \\
(0.102)\end{array}$ & & $\begin{array}{c}28.528 \\
(0.262)\end{array}$ & & $\begin{array}{l}83.485 \\
(1.197)\end{array}$ & & $\begin{array}{l}79.800 \\
(0.916)\end{array}$ \\
\hline \multicolumn{9}{|l|}{ (c)Early Strengthening Law } \\
\hline Capital ratio_t $\cdot$ EarlyD_t $t+1$ & & $\begin{array}{c}7.355 \\
(0.524)\end{array}$ & & $\begin{array}{c}9.494 \\
(0.728)\end{array}$ & & & & \\
\hline Tier1 ratio_t $\cdot$ EarlyD_t+1 & & & & & & $\begin{array}{l}24.673 \\
(1.611)\end{array}$ & & $\begin{array}{c}22.588 \\
(1.216)\end{array}$ \\
\hline EarlyD_t+1 & & $\begin{array}{l}-71.803 \\
(-0.474)\end{array}$ & & $\begin{array}{l}-93.530 \\
(-0.671)\end{array}$ & & $\begin{array}{l}-137.303 * \\
(-1.681)\end{array}$ & & $\begin{array}{r}-125.506 \\
(-1.181)\end{array}$ \\
\hline Obs. & 131 & 131 & 131 & 131 & 131 & 131 & 131 & 131 \\
\hline
\end{tabular}

$* 1 \mathrm{t}$-statistics in parentheses; ${ }^{*}$ Significant at $10 \% ; * *$ significant at $5 \% ; * * *$ significant at $1 \%$

*2 Method : Panel Generalized Method of Moments (Arellano and Bover [1995])

*3 The unit of $\Delta \log ($ Loan), Loan-Deposit interest rate spred, Capital ratio and Tier 1 ratio is \%

*4 The results reported are for the sample FY 1993-2006

*5 In the case of using equation (1)' and (3)', we examine the total effect of two capital injection policies: the Financial Function Stabilization Law and the Early Strengthening Law.

On the other hand, using equation (2)' and (4)', we separately examine the each effects of these two laws. 
Asia Pacific Economic Papers

Table 7 Robustness Check—domestic banks

Loan $=$ Total Loans

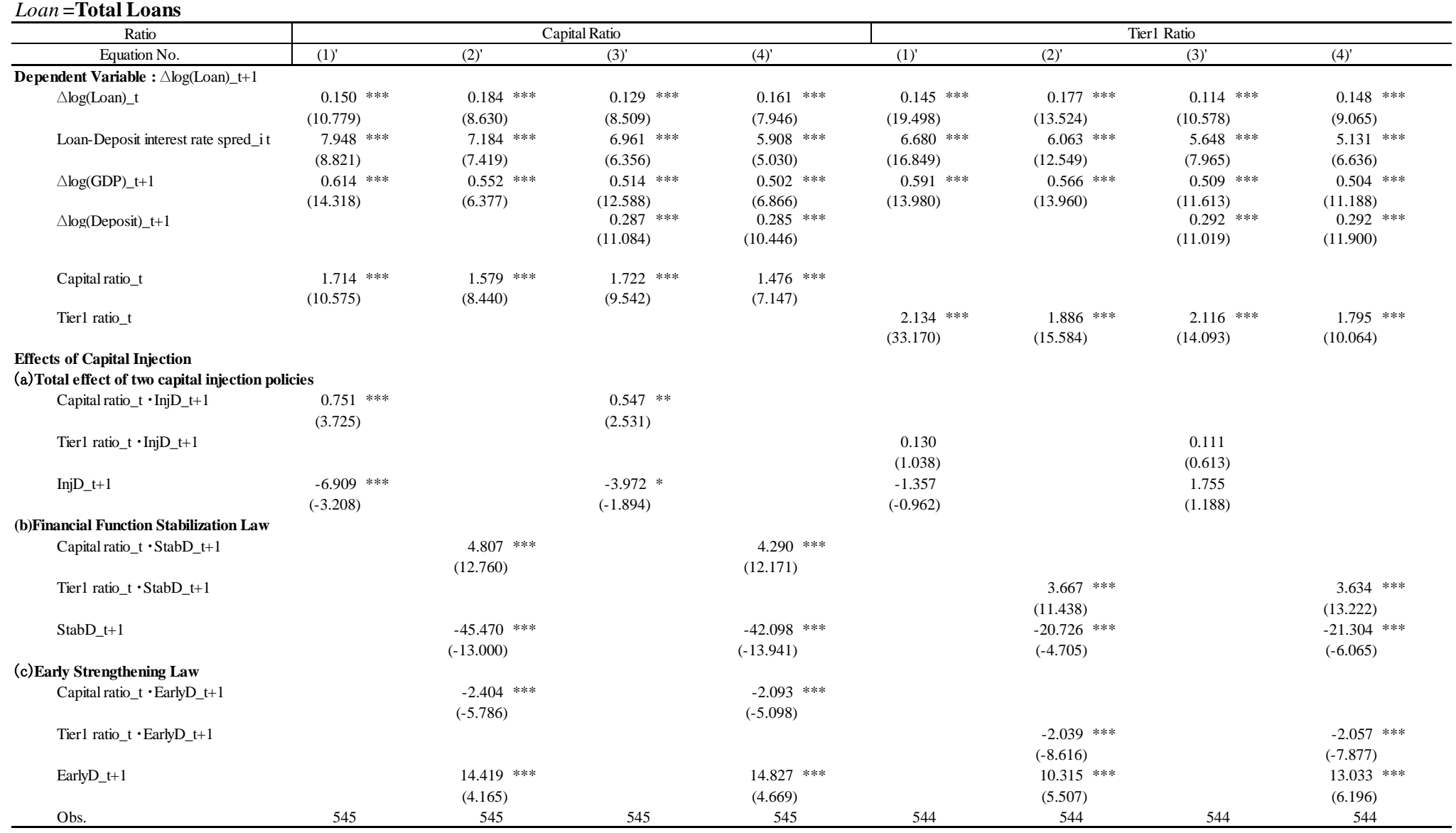


No. 391, 2011

Loan =SME Loans

\begin{tabular}{|c|c|c|c|c|c|c|c|c|}
\hline \multirow{2}{*}{$\begin{array}{c}\text { Ratio } \\
\text { Equation No. }\end{array}$} & \multicolumn{4}{|c|}{ Capital Ratio } & \multicolumn{4}{|c|}{ Tier1 Ratio } \\
\hline & $(1)^{\prime}$ & (2)' & (3)' & (4)' & $(1)^{\prime}$ & (2)' & (3)' & (4)' \\
\hline \multicolumn{9}{|l|}{ Dependent Variable $: \Delta \log (\operatorname{Loan}) \_t+1$} \\
\hline$\Delta \log ($ Loan $) \_t$ & $\begin{array}{l}0.131 \text { *** } \\
(11.711)\end{array}$ & $\begin{array}{l}0.090 \text { *** } \\
(5.463)\end{array}$ & $\begin{array}{l}0.105 * * * \\
(7.882)\end{array}$ & $\begin{array}{l}0.052 * * * \\
(2.694)\end{array}$ & $\begin{array}{l}0.112 \text { *** } \\
(10.818)\end{array}$ & $\begin{array}{l}0.087 \text { *** } \\
(5.569)\end{array}$ & $\begin{array}{l}0.091 \text { *** } \\
(8.755)\end{array}$ & $\begin{array}{l}0.045 \text { *** } \\
(2.937)\end{array}$ \\
\hline Loan-Deposit interest rate spred_it & $\begin{array}{l}5.771 \text { *** } \\
(7.521)\end{array}$ & $\begin{array}{l}2.693 \text { ** } \\
(2.405)\end{array}$ & $\begin{array}{l}5.631 \\
(10.055)\end{array}$ & $\begin{array}{l}2.010^{* *} \\
(2.115)\end{array}$ & $\begin{array}{l}4.710 * * * \\
(6.883)\end{array}$ & $\begin{array}{l}3.483 \text { *** } \\
(6.145)\end{array}$ & $\begin{array}{l}-4.283 \text { *** } \\
5.167497\end{array}$ & $\begin{array}{l}2.879 * * * \\
(4.836)\end{array}$ \\
\hline $\begin{array}{l}\Delta \log (\mathrm{GDP}) \_\mathrm{t}+1 \\
\Delta \log (\text { Deposit }) \_t+1\end{array}$ & $\begin{array}{l}0.814 \\
(14.523)\end{array}$ & $\begin{array}{l}0.700 \\
(10.014)\end{array}$ & $\begin{array}{l}-14.276 \text { *** } \\
(-6.381) \\
0.325 * * * \\
(15.940)\end{array}$ & $\begin{array}{c}0.651 \text { *** } \\
(12.577) \\
0.318 \text { *** } \\
(13.143)\end{array}$ & $\begin{array}{l}0.747 \text { *** } \\
(13.985)\end{array}$ & $\begin{array}{l}0.707 * * * \\
(10.420)\end{array}$ & $\begin{array}{c}0.697 \text { *** } \\
(14.067) \\
0.302 \\
(16.300)\end{array}$ & $\begin{array}{c}0.636 \text { *** } \\
(12.281) \\
0.322 \text { *** } \\
(13.914)\end{array}$ \\
\hline Capital ratio_t & $\begin{array}{l}1.291 \text { *** } \\
(6.396)\end{array}$ & $\begin{array}{l}0.679 \text { *** } \\
(3.052)\end{array}$ & $\begin{array}{l}0.748 \text { *** } \\
(17.538)\end{array}$ & $\begin{array}{l}0.455 * * \\
(2.214)\end{array}$ & & & & \\
\hline Tier1 ratio_t & & & & & $\begin{array}{l}1.515 \text { *** } \\
(14.367)\end{array}$ & ${ }^{1.019}{ }^{* * *}$ & $\begin{array}{l}1.157 \text { *** } \\
(8.246)\end{array}$ & $\begin{array}{l}0.729 \text { *** } \\
(7.100)\end{array}$ \\
\hline \multicolumn{9}{|c|}{$\begin{array}{l}\text { Effects of Capital Injection } \\
\text { (a)Total effect of two capital injection policies }\end{array}$} \\
\hline Capital ratio_t $\cdot$ InjD_t $t+1$ & $\begin{array}{l}2.505 * * * \\
(9.272)\end{array}$ & & $\begin{array}{l}1.173 * * * \\
(7.437)\end{array}$ & & & & & \\
\hline Tier1 ratio_t $\cdot$ InjD_t+1 & & & & & $\begin{array}{l}2.068 \text { *** } \\
(10.747)\end{array}$ & & $\begin{array}{l}2.500 * * * \\
(9.805)\end{array}$ & \\
\hline InjD_t+1 & $\begin{array}{l}-15.883 * * * \\
(-5.994)\end{array}$ & & $\begin{array}{l}2.593 * * * \\
(11.609)\end{array}$ & & $\begin{array}{l}-7.020 \text { *** } \\
(-5.169)\end{array}$ & & $\begin{array}{l}-7.163 * * * \\
(-4.431)\end{array}$ & \\
\hline \multicolumn{9}{|l|}{ (b)Financial Function Stabilization Law } \\
\hline Capital ratio_t $\cdot$ StabD_t $t+1$ & & $\begin{array}{l}5.416 \text { *** } \\
(12.451)\end{array}$ & & $\begin{array}{l}5.881 * * * \\
(15.597)\end{array}$ & & & & \\
\hline Tierl ratio_t $\cdot \mathrm{StabD}_{-} \mathrm{t}+1$ & & & & & & $\begin{array}{l}4.612 * * * \\
(12.579)\end{array}$ & & $\begin{array}{l}5.250 \text { *** } \\
(15.975)\end{array}$ \\
\hline StabD_t+1 & & $\begin{array}{l}-54.997 * * * \\
(-11.221)\end{array}$ & & $\begin{array}{l}-59.229 \text { *** } \\
(-16.278)\end{array}$ & & $\begin{array}{l}-35.081 * * * \\
(-7.572)\end{array}$ & & $\begin{array}{l}-36.362 \text { *** } \\
(-11.803)\end{array}$ \\
\hline \multicolumn{9}{|l|}{ (c)Early Strengthening Law } \\
\hline Capital ratio_t $\cdot$ EarlyD_t+1 & & $\begin{array}{c}-0.406 \\
(-1.010)\end{array}$ & & $\begin{array}{l}-0.561 * \\
(-1.743)\end{array}$ & & & & \\
\hline Tier1 ratio_t $\cdot$ EarlyD_t+1 & & & & & & $\begin{array}{c}-0.475 \\
(-1.254)\end{array}$ & & $\begin{array}{l}-0.629 * * \\
(-2.099)\end{array}$ \\
\hline EarlyD_t+1 & & $\begin{array}{c}4.099 \\
(1.101)\end{array}$ & & $\begin{array}{l}8.483 \text { *** } \\
(3.082)\end{array}$ & & $\begin{array}{l}5.5577^{* * *} \\
(2.721)\end{array}$ & & $\begin{array}{l}8.9744^{* * *} \\
(5.629)\end{array}$ \\
\hline Obs. & 539 & 539 & 539 & 539 & 538 & 538 & 538 & 538 \\
\hline
\end{tabular}

2 Method : Panel Generalized Method of Moments (Arellano and Bover [1995])

*3 The unit of $\Delta \log ($ Loan), Loan-Deposit interest rate spred, Capital ratio and Tier 1 ratio is \%

*4 The results reported are for the sample FY 1999-2006

*5 In the case of using equation (1)' and (3)', we examine the total effect of two capital injection policies: the Financial Function Stabilization Law and the Early Strengthening Law.

On the other hand, using equation (2)' and (4)', we separately examine the each effects of these two laws. 


\section{Bibliography}

Arellano, M., and O. Bover. (1995) "Another look at the instrumental variable estimation of errorcomponents models," Journal of Econometrics, Vol. 68, No. 1, pp. 29-51.

Baltagi, B. H. (2001) Econometric analysis of panel data, 2nded., Chichester, UK: Wiley

Bernanke, B. S., and C. S. Lown, "The Credit Crunch" Brookings Papers on Economic Activity, Vol. 1991, No. 2, pp. 205-247

Hall, B, J. (1993) "How has the Basle Accord Affected Bank Portfolios?" Journal of the Japanese and International Economies, Vol. 7, No. 4, pp. 408-440.

Himino, R. (2005) Kensyo BIS kisei to Nihon (Validation-the BIS regulation and Japan-), 2nd ed., Kinzai institute for financial affairs, inc.

Ito, T., and Y, N., Sasaki (1998) "Impacts of the Basel Capital Standard on Japanese Banks' Behavior", National Bureau of Economic Research Working Paper No.6730.

Ito, T., and Y, N., Sasaki (2002) "Impacts of the Basle Capital Standard on Japanese Banks' Behavior", Journal of the Japanese and International Economies, Vol. 16, No. 3, pp. 372-397.

Kasyap, A. K., and Stein, J. C. (2004) "Cyclical implications of the Basel-II capital standard," Economic perspectives, Federal Reserve Bank of Chicago, First Quarter. pp. 18-31.

Montgomery, H. (2005) "The effect of the Basel Accord on bank portfolios," Journal of the Japanese and International Economies, Vol. 19, No. 1, pp. 24-36.

Montgomery, H. and S., Shimizutani (2009) "The effectiveness of bank recapitalization policies in Japan," Japan and the World Economy, Vol. 21, No. 1, pp. 1-25.

Motonishi, Taizo, and Hiroshi Yoshikawa. (1999) "Causes of the Long Stagnation of Japan During the 1990s: Financial or Real?" Journal of the Japanese and International Economies,13:3, 181-200.

Peek, J. and E., Rosengren (1995) "The Capital Crunch: Neither a Borrower nor a Lender Be," Journal of Money, Credit, and Banking, Vol. 27, No. 3, pp. 625-638.

Santos, J., A., C. (2001) "Bank Capital Regulation in Contemporary Banking Theory: A Review of the Literature," Financial Markets, Institutions \& Instruments, V. 10, No. 2, pp.41- 84

Vera, D. and K. Onji (2008) "Change in the banking system and small business lending," Small Business Economics, forthcoming.

Watanabe, W. (2007) "Prudential Regulation and the "Credit Crunch": Evidence from Japan," Journal of Money, Credit and Banking, Vol. 39, No. 2-3, pp.639-665.

Woo, D. (2003) "In Search of "Capital Crunch": Supply Factors Behind the Credit Slowdown in Japan," Journal of Money, Credit and Banking, Vol. 35, No. 6, Part 1, pp. 1019-1038. 


\section{Previous Asia Pacific Economic Papers}

390 Capital Injection, Restructuring Targets and Personal Management: The Case of Japanese Regional Banks Kazuki Onji, David Vera, Jenny Corbett, 2011

389 Beyond 'Asian Values': Rationales for Australian-Japan Cooperation in Asian Regionalism GO ITO, 2010

388 How Does a Decrease in Oil Production Affect the World Economy?

Naobiko Yahaba, 2010

387 Internal Promotion and the Effect of Board Monitoring: a Comparison of Japan and the United States

Meg Sato, 2010

386 Interaction between trade, conflict and cooperation: the case of Japan and China

Shiro Armstrong, 2010

385 Japanese Aid as a prerequisite for FDI: the case of Southeast Asian countries

Séverine Blaise, 2009

384 Insular Decision-making in the Board Room: Why Boards Retain and Hire Sub-Standard CEOs

Meg Sato, 2009

383 How does Financial System Efficiency Affect the Growth Impact of FDI in China?

Ying $X u, 2009$

382 A Tale of Pork Prices: Evasion and Attenuation of a Japanese Tariff

Kazuki Onji, 2009

381 Are the East Asian Currencies Still Misaligned? An Analysis Based on Absolute Income Relationship

Using Panel Data

Taizo Motonishi, 2009

380 Is Foreign Aid a Vanguard of Foreign Direct Investment? A Gravity-Equation Approach

Hidemi Kimura and Yasuyuki Todo, 2009

379 Rain, Elections and Money: The Impact of Voter Turnout on Distributive Policy Outcomes in Japan

Yusaku Horiuchi and Jun Saito, 2009

378 Japanese FDI in China: determinants and performance

Shiro Armstrong, 2009

377 Expansion Abroad and Jobs at Home: Evidence from Japanese Multinational Enterprises

Nobuaki Yamashita and Kyoji Fukao, 2009

376 Should Australia Encourage Developing Countries to Adopt Competition Laws?

Henry Ergas, 2008

375 Will New Trends in Foreign Direct Investment Change the Structure of Intra-industry Trade between China and Japan?

Tao Tao, 2008

374 Competition Policy in ASEAN: Case studies

Johannah Branson, 2008

373 Can the New Antimonopoly Act Change the Japanese Business Community? The 2005 Amendment to Antimonopoly Act and Corporate Compliance.

Kazukiyo Onishi, 2008 
Asia Pacific Economic Papers

\title{
Annual subscription rate for up to eight issues:
}

\author{
Individuals A\$65.00 (includes GST) A \$60 (overseas) \\ Institutions A $\$ 10.00$ (includes GST) A \$100 (overseas)
}

\section{Cost for single issues:}

\author{
A $\$ 16.50$ (includes GST) A $\$ 15.00$ (overseas) \\ A $\$ 10.00$ (Students) \\ No postage required within Australia
}

Available from:

Centre Administrator

Australia-Japan Research Centre

Crawford School of Economics and Government

ANU College of Asia and the Pacific

The Australian National University

Canberra ACT 0200, Australia

Facsimile: (61 2) 61258448

Telephone: (61 2) 61253780

Email: ajrc@anu.edu.au

URL: http:/www.crawford.anu.edu.au 